Key Words:

Supernate Composition

Sample Analysis

Retention: Permanent

Key WTP R\&T References:

Test Specification: 24590-WTP-RT-01-001

Task Plan: WSRC-TR-2001-00244

Test Exceptions: None

R\&T Focus Area: Characterization

Test Scoping Statement: S-2

\title{
CHARACTERIZATION, DILUTION, AND AGING STUDY OF A RIVER PROTECTION PROJECT SAMPLE FROM TANK 241-AW-101 (U)
}

\author{
M. S. Hay, SRTC/WPT \\ C. J. Coleman, SRTC/ADS \\ K. B. Martin, SRTC/WPT
}

NOVEMBER 2003

Westinghouse Savannah River Company

Savannah River Site

Aiken, SC 29808

Prepared for the U.S. Department of Energy Under Contract Number DE-AC09-96SR18500

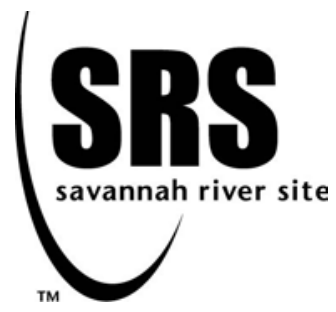


This document was prepared in conjunction with work accomplished under Contract No. DE-AC09-96SR18500 with the U. S. Department of Energy.

\section{DISCLAIMER}

This report was prepared as an account of work sponsored by an agency of the United States Government. Neither the United States Government nor any agency thereof, nor any of their employees, makes any warranty, express or implied, or assumes any legal liability or responsibility for the accuracy, completeness, or usefulness of any information, apparatus, product or process disclosed, or represents that its use would not infringe privately owned rights. Reference herein to any specific commercial product, process or service by trade name, trademark, manufacturer, or otherwise does not necessarily constitute or imply its endorsement, recommendation, or favoring by the United States Government or any agency thereof. The views and opinions of authors expressed herein do not necessarily state or reflect those of the United States Government or any agency thereof.

This report has been reproduced directly from the best available copy.

Available for sale to the public, in paper, from: U.S. Department of Commerce, National Technical Information Service, 5285 Port Royal Road, Springfield, VA 22161, phone: (800) 553-6847, fax: (703) 605-6900

email: orders@ntis.fedworld.gov

online ordering: http://www.ntis.gov/help/index.asp

Available electronically at http://www.osti.gov/bridge

Available for a processing fee to U.S. Department of Energy and its contractors, in paper, from: U.S. Department of Energy, Office of Scientific and Technical Information, P.O. Box 62, Oak Ridge, TN 37831-0062,

phone: (865)576-8401,

fax: (865)576-5728

email: $\underline{\text { reports@ adonis.osti.gov }}$ 
WSRC-TR-2003-00379, REV. 0

SRT-RPP-2003-00181, REV. 0

\section{TABLE OF CONTENTS}

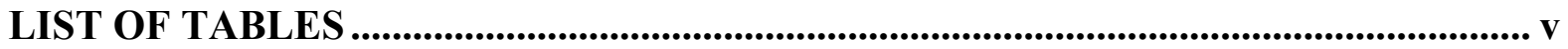

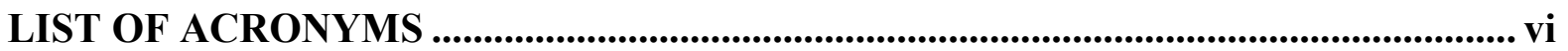

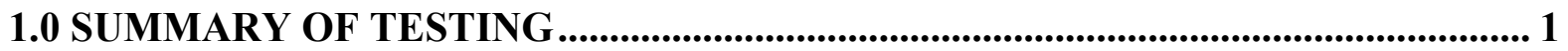

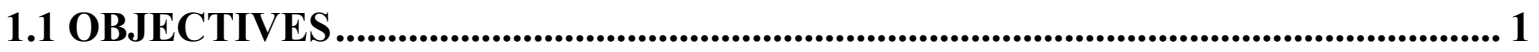

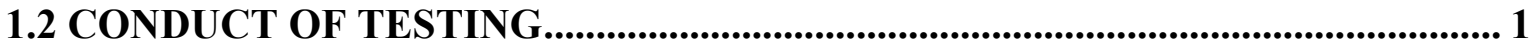

1.3 RESULTS AND PERFORMANCE AGAINST OBJECTIVES ............................. 2

1.4 QUALITY REQUIREMENTS............................................................................... 2

1.5 ISSUES ............................................................................................................... 2

2.0 DILUTION TO 7 M SODIUM AND 6-MONTH AGING STUDY .............................. 3

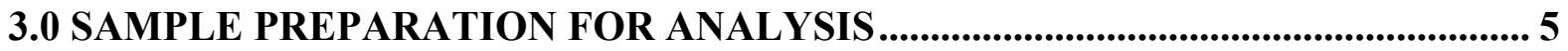

3.1 PREPARATION OF SAMPLES FOR THE ANALYSIS OF LIQUID

FRACTIONS............................................................................................................ 5

3.2 DOSE RATE LIMITS FOR ANALYTICAL LABORATORIES ......................... 5

4.0 DENSITY AND WEIGHT PERCENT SOLIDS MEASUREMENTS ......................... 7

5.0 ANALYTICAL RESULTS AND DATA EVALUATION ......................................... 9

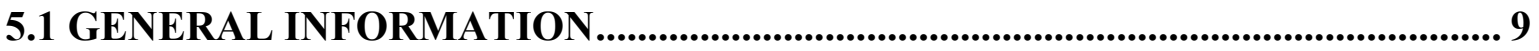

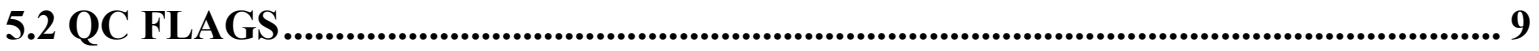

5.3 DATA EVALUATION..................................................................................... 10

5.3.1 Discussion of Table 5-2, Physical Properties of the Un-Aged 7 M Diluted 241AW-101 Sample................................................................................................. 10

5.3.2 Discussion of Table 5-3, Physical Properties of the Aged 7 M Diluted 241-AW101 Sample ....................................................................................................... 10

5.3.3 Discussion of Table 5-4, Composition of the Un-Aged 7 M Diluted 241-AW-101 Sample.

5.3.4 Discussion of Table 5-5, Composition of the Aged 7 M Diluted 241-AW-101

5.3.5 Discussion of Table 5-6, Comparison of the Un-Aged and Aged 7 M Diluted 11 241-AW-101 Sample ......................................................................................................... 14

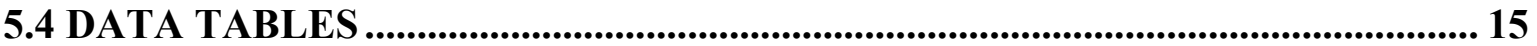

6.0 GENERAL DESCRIPTION OF ANALYTICAL PROCEDURES .......................... 31

6.1 INDUCTIVELY COUPLED PLASMA-ATOMIC EMISSION SPECTROSCOPY

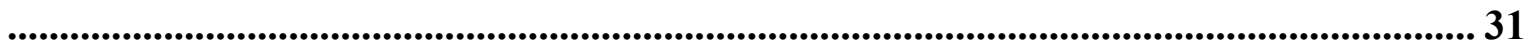

6.2 ION CHROMATOGRAPHY FOR ANIONS AND ORGANICS ACIDS ............ 31

6.3 FREE HYDROXIDE AND TOTAL BASE TITRATIONS ................................. 31

6.4 ATOMIC ABSORPTION SPECTROSCOPY ...................................................... 32

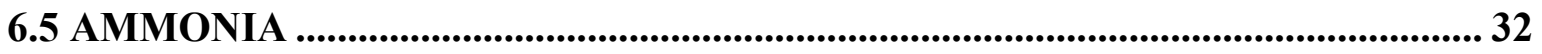

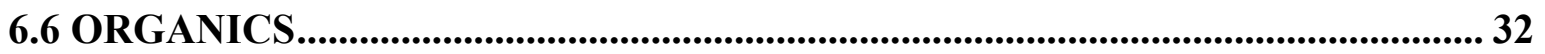

6.7 TOTAL INORGANIC CARBON/TOTAL ORGANIC CARBON ........................ 32

6.8 INDUCTIVELY COUPLED PLASMA-MASS SPECTROMETRY ..................... 33

6.9 ALPHA COUNTING .......................................................................................... 33

6.10 GAMMA SPECTROMETRY ....................................................................... 33

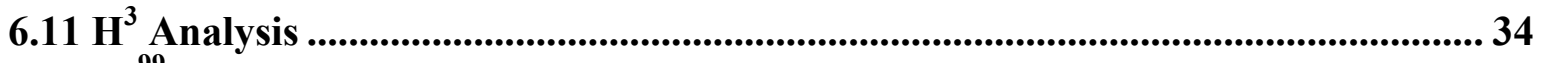

$6.12 \mathrm{Te}^{99}$ ANALYSIS (FOR PERTECHNETATE FORM) ........................................ 34 
WSRC-TR-2003-00379, REV. 0

SRT-RPP-2003-00181, REV. 0

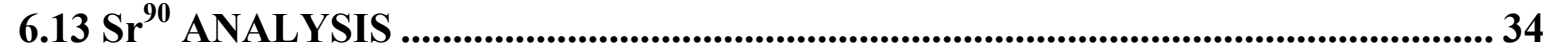

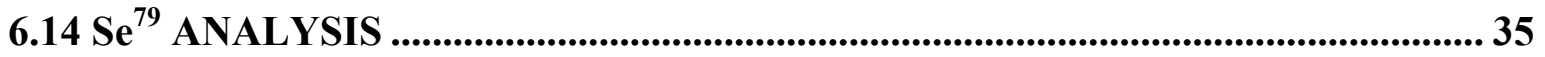

6.15 ALPHA SPECTROSCOPY FOR PLUTONIUM ISOTOPICS.............................. 35

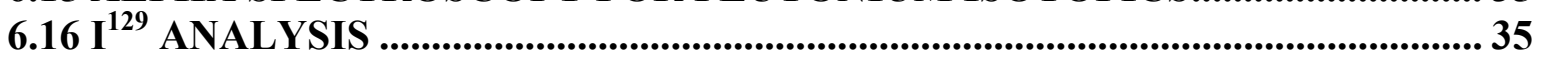

6.17 Am/Cm ANALYSIS ....................................................................................................... 36

6.18 C ${ }^{14}$ ANALYSIS ................................................................................................................... 36

7.0 REFERENCES............................................................................................................. 37 


\section{LIST OF TABLES}

Table 5-1. Abbreviations of Analytical Methods Used in Tables 5-2 through 5-6 ............. 16

Table 5-2. Physical Properties of the Un-Aged 7 M Diluted 241-AW-101 Sample ............ 17

Table 5-3. Physical Properties of the Aged 7 M Diluted 241-AW-101 Sample................... 17

Table 5-4. Composition of the Un-Aged 7 M Diluted 241-AW-101 Sample ..................... 18

Table 5-5. Composition of the Aged 7 M Diluted 241-AW-101 Sample........................... 22

Table 5-6. Comparison of Un-Aged and Aged 7 M Diluted 241-AW-101 Sample............ 26 
WSRC-TR-2003-00379, REV. 0

SRT-RPP-2003-00181, REV. 0

\section{LIST OF ACRONYMS}

RPP-WTP River Protection Project-Waste Treatment Plant

SRTC Savannah River Technology Center

QC

Quality Control

LCS Laboratory Control Standard

MS Matrix Spike

ICP-ES Inductively Coupled Plasma- Emission Spectroscopy

AA

Atomic Absorption Spectroscopy

ADS Analytical Development Section

MRQ Minimum Reportable Quantity

\%RSD Percent Relative Standard Deviation

DL Detection Limit

IPC Ion Pair Chromatography

IC Ion Chromatography

PT Ammonia Purge and Trap

$\mathrm{T} \quad$ Titration

IE ICP-ES

IM ICP-MS

A Acidification

GS Gamma Spectroscopy

SG Separation/Gamma Spectroscopy

SA Separation/Alpha Spectroscopy

SL Separation/Liquid Scintillation

AC Alpha Counting

HL High Pressure Liquid Chromatography (HPLC)

GM Gas Chromatography-Mass Spectroscopy (GC-MS) 
WSRC-TR-2003-00379, REV. 0

SRT-RPP-2003-00181, REV. 0

\subsection{SUMMARY OF TESTING}

As part of the program to provide pretreatment development and testing services to support the River Protection Project-Waste Treatment Plant (RPP-WTP) mission to treat Hanford tank waste, a $\sim 15 \mathrm{~L}$ sample of waste from Tank 241-AW-101 was received at the Savannah River Technology Center (SRTC). The waste sample was characterized and diluted to provide feed for pretreatment testing. The characterization data provides a basis for rational development of pretreatment processes, determination of reagent requirements, verification of tank composition, and development of physical design parameters for the pretreatment plant.

\subsection{OBJECTIVES}

A previously issued report provided the characterization of the as-received 241-AW-101 and the 241-AW-101 sample diluted to a $5 \mathrm{M}$ sodium concentration. ${ }^{1}$ This second report on the 241-AW-101 sample describes the composition of the sample diluted to $7 \mathrm{M}$ sodium and provides a comparison to $7 \mathrm{M}$ diluted sample after six months of aging. The objectives of the task include:

- Dilute a portion of the 241-AW-101 sample to a sodium concentration of $7 \mathrm{M}$.

- Analyze the diluted $7 \mathrm{M}$ sample.

- Store the $7 \mathrm{M}$ diluted sample for 6 months and re-analyze the sample.

- Report the results of the analysis.

\subsection{CONDUCT OF TESTING}

A $500 \mathrm{~mL}$-sample of the as-received 241-AW-101 was diluted with $250 \mathrm{~mL}$ of deionized, distilled water to bring the sodium concentration to $7.41 \mathrm{M}$, as determined by ICP-ES and $6.70 \mathrm{M}$ as determined by AA (average of all 6 results $=7.05 \mathrm{M}, 5.7 \% \mathrm{RSD}$ ). The weight percent insoluble (undissolved) solids of the sample were determined to be $0.32 \mathrm{wt} \%$. The filtered supernate of the diluted sample was obtained for analysis. Analysis of the insoluble solids was not required since the weight percent insoluble solids was determined to be less than $2 \mathrm{wt} \%$. Samples of the filtered supernate and the diluted slurry were retained for six months to determine the effects of aging on the sample composition.

After six months, a visual examination of the samples found no observable precipitation of solids in either the filtered supernate or slurry samples. The weight percent insoluble (undissolved) solids of the slurry sample were determined to be $0.14 \mathrm{wt} \%$. This value is biased low due to the adhesion of solids to the filtration apparatus. The filtered supernate of the slurry sample was obtained for analysis. 
WSRC-TR-2003-00379, REV. 0

SRT-RPP-2003-00181, REV. 0

\subsection{RESULTS AND PERFORMANCE AGAINST OBJECTIVES}

The main objectives of the $7 \mathrm{M}$ dilution and aging study for the 241-AW-101 sample were met. However, as part of the reporting objective, data quality requirements were specified for each analyte. Due to the radioactive nature of the sample, dilutions of the raw samples were required to allow removal from the Shielded Cells facility for analysis. These dilutions combined with the presence of very low concentrations of some analytes in the sample make it difficult to meet all the data quality requirements for all analytes. In those limited cases where the data quality requirements were not met, quality control (QC) flags in the data tables identify the specific criteria not met.

\subsection{QUALITY REQUIREMENTS}

This work was conducted in accordance with the RPP-WTP QA requirements specified for work conducted by SRTC as identified in DOE IWO MOSRLE60. SRTC has provided matrices to RPP-WTP demonstrating compliance of the SRTC QA program with the requirements specified by RPP-WTP. Specific information regarding the compliance of the SRTC QA program with RW-0333P, Revision 10, NQA-1 1989, Part 1, Basic and Supplementary Requirements and NQA-2a 1990, Subpart 2.7 is contained in these matrices.

Overall, the data quality for the analysis of the 241-AW-101 sample was reasonably good. The quality control of the sample analysis consisted of the use of triplicate sample analysis, blanks, laboratory control standards (LCS), and a matrix spike (MS).

The characterization task was conducted under an approved task and quality assurance plan ${ }^{2}$ based on a test specification issued by RPP-WTP. ${ }^{3}$ The characterization data represents the composition of the 241-AW-101 sample received at SRTC and makes no assertions as to the validity of the data with respect to the tank contents as a whole or to any feed delivered from this tank. Recent experience at SRS indicates a combined sampling and analytical error on the order of $15-20 \%$ associated with obtaining small samples from a well mixed waste tank. $^{4}$

\subsection{ISSUES}

None 
WSRC-TR-2003-00379, REV. 0

SRT-RPP-2003-00181, REV. 0

\subsection{DILUTION TO 7 M SODIUM AND 6-MONTH AGING STUDY}

A $500 \mathrm{~mL}$ sample of the as-received 241-AW-101 was diluted with $225 \mathrm{~mL}$ deionized, distilled water. An analysis of the filtered supernate after the dilution indicated the sodium concentration was $7.78 \mathrm{M}$ by inductively coupled plasma- emission spectroscopy (ICP-ES) and 7.24 $\mathrm{M}$ by atomic absorption spectroscopy (AA). A second dilution was made based on the average sodium concentration of the two analytical methods using $25 \mathrm{~mL}$ of deionized distilled water. The analysis of the filtered supernate after the second dilution found the sodium concentration to be $7.41 \mathrm{M}$ by ICP-ES and $6.70 \mathrm{M}$ by AA. The average sodium concentration of all six replicates analyzed by the two methods was $7.05 \mathrm{M}(5.7 \% \mathrm{RSD})$.

The weight percent of insoluble (undissolved) solids of the sample was determined by filtering $35.969 \mathrm{~g}$ of the $7 \mathrm{M} 241-\mathrm{AW}-101$ sample through a pre-weighed $0.45 \mu$ nylon filter disc. The filtration yielded $0.266 \mathrm{~g}$ of wet solids. Upon drying at $100^{\circ} \mathrm{C}$ to constant weight, $0.115 \mathrm{~g}$ of dry solids were obtained indicating a weight percent insoluble solids of $0.32 \mathrm{wt} \%$. The density and weight percent total solids of the sample were also measured. The filtered supernate of the diluted sample was obtained for analysis. The analysis of the insoluble solids was not required since the weight percent insoluble solids was determined to be less than $2 \mathrm{wt} \%$. Samples of the filtered supernate and the diluted slurry were retained for six months to determine the effects of aging on the sample composition. The samples were stored in tightly capped polyethylene bottles.

After six months, a visual examination of the samples found no observable precipitation of solids in the either the filtered supernate or slurry samples. The slurry sample was filtered through a $0.45 \mu$ nylon filter disc. The filter disc had been pre-weighed to allow determination of the weight percent insoluble solids during the solids separation. Unfortunately, an appreciable quantity of the wet solids adhered to the sides of the filtration cup and could not be retrieved when the filter disc was removed for drying. The weight of dry solids obtained from the filtration of $628.357 \mathrm{~g}$ of the sample was $0.852 \mathrm{~g}$. This indicated a weight percent insoluble (undissolved) solids of the slurry sample of $0.14 \mathrm{wt} \%$. This value is biased low due to the adhesion of solids to the filtration apparatus. The filtered supernate of the slurry sample was submitted for analysis. 
WSRC-TR-2003-00379, REV. 0

SRT-RPP-2003-00181, REV. 0

This page intentionally left blank. 
WSRC-TR-2003-00379, REV. 0

SRT-RPP-2003-00181, REV. 0

\subsection{SAMPLE PREPARATION FOR ANALYSIS}

\subsection{PREPARATION OF SAMPLES FOR THE ANALYSIS OF LIQUID FRACTIONS}

Samples of supernate were obtained by vacuum filtering a portion of the sample through a $0.45 \mu$ Nylon filter disc. Portions of the filtered supernate were diluted with deionized distilled water or nitric acid to reduce the sample activity and allow removal from the Shielded Cells for chemical characterization. Generally, a 15 -20-fold dilution was required on supernate samples to meet the dose limits for the analytical laboratories. All sample preparations of the filtered supernate samples were conducted in triplicate. Supernate samples were analyzed for species listed in Table 2 of the test specification. Section 5.0 presents the results of the analysis of the $7 \mathrm{M}$ diluted 241-AW-101 sample. The weight of the solids collected was recorded to calculate the weight percent of damp vacuum filtered solids. Solids collected on the filter were not washed to remove interstitial supernate.

A blank was prepared concurrently with the sample preparations substituting deionized distilled water in place of the sample aliquot.

Additional sample preparations specific to individual analytical methods were conducted by the Analytical Development Section (ADS) on the samples removed from the Shielded Cells as necessary.

\subsection{DOSE RATE LIMITS FOR ANALYTICAL LABORATORIES}

Samples sent to the analytical laboratories require dose rates of $<10 \mathrm{mrem} / \mathrm{hr}$ whole body dose and $<1000 \mathrm{mrem} / \mathrm{hr}$ extremity dose. In order to avoid exceeding the dose rate limits and the need for re-preparing the samples, dilutions were made targeting a whole body dose rate of between 2 - $5 \mathrm{mrem} / \mathrm{hr}$. This working dose rate range provides some cushion against the unavoidable presence of contamination on the outside of the sample bottles. Additionally, sample handling in the cells, such as pipetting, weighing, or transferring from one container to another invariably leads to some contamination of the sample. Efforts to minimize the level of contamination include regular cleaning of the manipulator fingers, cleaning of cell surfaces, and the use of clean supplies. Blanks prepared in the Shielded Cells in the same manner as the sample provide some indication of the level of contamination introduced. 
WSRC-TR-2003-00379, REV. 0

SRT-RPP-2003-00181, REV. 0

This page intentionally left blank. 
WSRC-TR-2003-00379, REV. 0

SRT-RPP-2003-00181, REV. 0

\subsection{DENSITY AND WEIGHT PERCENT SOLIDS MEASUREMENTS}

The weight percent of total solids in the samples was measured in the Shielded Cells using a conventional drying oven at $100{ }^{\circ} \mathrm{C}$. The weight percent dissolved solids in a sample of the filtered supernate were measured in the same manner. The weight percent of insoluble solids was measured by filtering a known weight of the sample through a pre-weighed $0.45 \mu$ nylon filter disc. The filter disc and solids obtained were dried using a conventional drying oven at $100{ }^{\circ} \mathrm{C}$. The weight percent vacuum filtered solids were measured by filtering a known weight of the sample and determining the weight of damp solids recovered. All filtrations were made through a $0.45 \mu$ Nylon membrane. All measurements were made in triplicate.

$\mathrm{Wt} \%$ dissolved solids

$\mathrm{Wt} \%$ total solids

$\mathrm{Wt} \%$ insoluble solids

$\mathrm{Wt} \%$ vacuum filterable solids (wt dissolved solids/wt of supernate) x 100 (wt total solids/wt of total sample) x 100 (wt insoluble solids/wt of total sample) x 100 (wt of damp solids/wt of total sample) x 100

Density measurements were made in the Shielded Cells on both the total sample and the filtered supernate. The temperature in the Shielded Cells varies between $\sim 18-25^{\circ} \mathrm{C}$, depending on the temperature outside the building. The temperature was recorded for all density measurements and noted in the tables of analytical results. 
WSRC-TR-2003-00379, REV. 0

SRT-RPP-2003-00181, REV. 0

This page intentionally left blank. 
WSRC-TR-2003-00379, REV. 0

SRT-RPP-2003-00181, REV. 0

\subsection{ANALYTICAL RESULTS AND DATA EVALUATION}

\subsection{GENERAL INFORMATION}

Table 5-1 through Table 5-6 provide the physical properties and chemical and radiochemical composition of the Un-Aged and Aged $7 \mathrm{M}$ diluted samples of the 241-AW-101 tank waste sample received at SRTC. The tables include the results of all replicates, blanks, laboratory control and matrix spike recoveries, and quality control flags within each table to allow easy identification of data quality. Analytical results for liquid samples use units of $\mathrm{mg} / \mathrm{L}$ or $\mathrm{mCi} / \mathrm{L}$. The following list identifies the data tables included in this section with a brief description of the sample analyzed:

Table 5-1. Abbreviations of Analytical Methods Used in Tables 5-2 through 5-6

Table 5-2. Physical Properties of the Un-Aged 7 M Diluted 241-AW-101 Sample

Table 5-3. Physical Properties of the Aged 7 M Diluted 241-AW-101 Sample

Table 5-4. Composition of the Un-Aged 7 M Diluted 241-AW-101 Sample.

Table 5-5. Composition of the Aged 7 M Diluted 241-AW-101 Sample

Table 5-6. Comparison of Un-Aged and Aged 7 M Diluted 241-AW-101 Sample

\subsection{QC FLAGS}

The analytical results in tables include a QC flag in the last column to indicate failure to meet the quality control requirements stated in the test specification. The test specification and approved task plan for the characterization of the 241-AW-101 samples set requirements for the minimum reportable quantity (MRQ), the percent relative standard deviation (\%RSD) for the three replicate samples, the percent recovery of the laboratory control standard (LCS), and the percent recovery of the matrix spike (MS) in the analysis of each analyte. In addition, analyses in which the concentration of the analyte in the blank exceeded 5\% of the concentration in the sample were flagged. Results where the analyte concentration was less than ten times the estimated detection limit (DL) for the analyte were also flagged. The DL for the analyte was determined based on the analysis of high purity standards. Values less than ten times the DL typically have greater uncertainty. 
The following defines the QC flags used in the tables:

None Analyte meets all QC requirements.

$\mathrm{U}_{\mathrm{M}} \quad$ Analyte does not meet the MRQ requirement.

$\mathrm{U}_{\mathrm{R}} \quad$ Analyte does not meet the \%RSD requirement.

$\mathrm{U}_{\mathrm{L}} \quad$ Analyte does not meet the percent recovery of the LCS requirement.

$\mathrm{U}_{\mathrm{S}} \quad$ Analyte does not meet the percent recovery of the MS requirement.

$\mathrm{U}_{\mathrm{B}} \quad$ Analyte concentration in the blank exceeds $5 \%$ of the concentration measured in the sample.

$\mathrm{U}_{\mathrm{E}} \quad$ Analyte concentration measured at less than ten times the DL for the sample.

In general, most of the QC failures can be attributed to low concentrations present in the sample exacerbated by the dilution necessary to allow removal of the samples from the Shielded Cells for analysis in the ADS laboratory hoods. In particular, meeting the MRQ requirement depends heavily on the dilution required for handling the sample. In other cases, extensive sample preparation in the Shielded Cells leads to contamination of the sample as evidenced by significant concentrations of radionuclides in the blanks. The presence of contamination in the sample generally leads to large \%RSD for the replicate analyses. With the low concentration of many of the radionuclides in the sample, a small amount of contamination in either the initial sample or during the preparation of analytical samples can lead to large errors in the measurement.

\subsection{DATA EVALUATION}

\subsubsection{Discussion of Table 5-2, Physical Properties of the Un-Aged 7 M Diluted 241-AW-101 Sample}

The weight percent dissolved solids of the Un-Aged $7 \mathrm{M}$ diluted 241-AW-101 appears to be low based on the density of $1.38 \mathrm{~g} / \mathrm{mL}$ and $7 \mathrm{M}$ sodium concentration of the solution. Based on past experience, a $7 \mathrm{M}$ sodium solution should have a weight percent dissolved solids of $\sim 40 \mathrm{wt} \%$. The discrepancy was not realized until the completion of the 6-month aging study, at which point a re-analysis was not possible.

\subsubsection{Discussion of Table 5-3, Physical Properties of the Aged 7 M Diluted 241-AW- 101 Sample}

The weight percent of insoluble solids was measured during the filtration of the entire aged sample. Although the sample has a very low insoluble solids content, the large volume of sample filtered produced enough solids to cause problems with the weight percent insoluble solids determination. Solids adhered to the side walls of the filtration apparatus and could not effectively be removed with the filter disc. Therefore, the values for both the weight percent insoluble solids and the weight percent vacuum filterable solids were biased low. 
WSRC-TR-2003-00379, REV. 0

SRT-RPP-2003-00181, REV. 0

\subsubsection{Discussion of Table 5-4, Composition of the Un-Aged 7 M Diluted 241-AW-101 Sample}

- Reasonable agreement (14\% difference) was obtained for the cation/anion balance although the anion concentration appears slightly low. Using the sodium and potassium values from AA for the cation concentration yields $7.45 \mathrm{M}$. Summing the concentrations of free hydroxide, Al from ICP-ES, TIC calculated as a carbonate concentration, and the anions obtained from IC produces an anion concentration of 6.53 M. Substituting the sodium value from ICP-ES raises the cation concentration to $8.16 \mathrm{M}$ and percent difference to $24 \%$.

- Sodium concentrations obtained from ICP-ES and AA show good agreement with a difference of only $11 \%$.

- Potassium concentrations obtained from ICP-ES and AA show good agreement with a difference of only $7 \%$.

- Poor agreement was obtained between the phosphorus concentrations from IC and ICP-ES. Comparing the molarity of phosphate as determined by IC with the molarity of phosphorus from ICP-ES shows a difference of $2 \mathrm{X}$. The phosphorus concentration in the sample is quite low and was less than 10 times the detection limit for the IC analysis. The low concentrations of sulfur in the sample may explain the $4 \mathrm{X}$ difference between the results from the IC and ICP-ES for that element.

- Approximately $1 / 3$ of the total organic carbon remains unaccounted for after summing the carbon contribution from formate, oxalate, acetate, and glycolate from the IC and comparing to the results of the TOC analysis.

- The $\mathrm{Cs}^{137}$ value from gamma counting shows good agreement with the value obtained from the ICP-MS with a difference of only $7 \%$. Similarly the $\mathrm{Tc}^{99}$ values from counting and the ICP-MS method show a difference of only $15 \%$.

- The $\mathrm{Pu}^{239 / 240}$ result from ICP-MS and counting methods show a $2 \mathrm{X}$ difference. The ICP-MS value for $\mathrm{Pu}^{239}$ is less than 10 times the detection limit.

- For the anion analysis (IC designator in the table) several analytes $\left(\mathrm{PO}_{4}{ }^{3-}, \mathrm{SO}_{4}{ }^{2-}\right.$, $\mathrm{C}_{2} \mathrm{O}_{4}{ }^{2-}, \mathrm{F}^{-}, \mathrm{CHO}_{2}{ }^{-}$) were flagged for values less than $10 \mathrm{X}$ the detection limit.

- $\mathrm{Ca}$ and $\mathrm{U}$ from the ICP-ES analysis were flagged for results less than 10X the detection limits. Both $\mathrm{Li}$ and $\mathrm{Ce}$ were flagged for not meeting the required MRQ. The Li detection limit was $\sim 5 \mathrm{X}$ the MRQ, while the Ce detection limit was $\sim 3 \mathrm{X}$ the required $M R Q$.

- The result for $\mathrm{Hg}(<2.2 \mathrm{mg} / \mathrm{L})$ was flagged for not meeting the MRQ of $1.5 \mathrm{mg} / \mathrm{L}$. 
- $\quad$ The results for citrate, EDTA, and HEDTA were flagged for not meeting the MRQ. However, as stated in the task plan, these analytes were provided as information only since there was insufficient method data to set QC parameters. The QC parameters were provided as target values.

- The $\mathrm{I}^{127}$ result was flagged due to the blank showing a concentration greater than 5\% of the sample result. The matrix spike recovery was also high. However, the $\mathrm{I}^{127}$ value from ICP-MS is unreliable due to memory effects.

- The $\mathrm{W}$ result from the ICP-MS was flagged due to a matrix spike recovery slightly higher than the required $75-130 \%$.

- The non-cesium gamma emitters $\left(\mathrm{Eu}^{154}, \mathrm{Eu}^{155}, \mathrm{Co}^{60}, \mathrm{Sn}^{126}\right.$, and $\left.\mathrm{Pa}^{231}\right)$ were all flagged for not meeting the MRQ. A cesium separation/extended counting was not performed on the sample. However, a cesium separation/extended counting was performed on the aged $7 \mathrm{M}$ sample (see Table 5-5).

- The $\mathrm{C}^{14}$ results were flagged for being less than 10 times the detection limits.

- The $\mathrm{Pu}^{238}$ results were flagged for not meeting the required \%RSD of $15 \%$, however the values are over an order of magnitude lower than the required MRQ.

- The $\mathrm{Cm}^{243 / 244}$ values were flagged for not meeting the required \%RSD and the blank having a concentration greater than $5 \%$ of the sample concentration. The blank indicates some curium contamination of the sample, which also accounts for the high scatter in the sample results.

- The $\mathrm{U}^{235}$ and $\mathrm{Pu}^{239}$ results from the ICP-MS were flagged for being less than 10 times the detection limits.

- The gross alpha results were flagged for an \%RSD slightly higher than the required $15 \%$. The results were also flagged for being less than 10 times the detection limits.

\subsubsection{Discussion of Table 5-5, Composition of the Aged 7 M Diluted 241-AW-101 Sample}

- Good agreement (3\% difference) was obtained for the cation/anion balance. Using the sodium and potassium values from AA for the cation concentration yields $7.82 \mathrm{M}$. Summing the concentrations of free hydroxide, Al from ICP-ES, TIC calculated as a carbonate concentration, and the anions obtained from IC produces an anion concentration of $7.57 \mathrm{M}$. Substituting the sodium value from ICP-ES in place of the AA value raises the cation concentration to $7.85 \mathrm{M}$ and percent difference to $4 \%$.

- Sodium concentrations obtained from ICP-ES and AA show good agreement with a difference of $<1 \%$.

- Potassium concentrations obtained from ICP-ES and AA show good agreement with a difference of $3 \%$. 
- Approximately $1 / 3$ of the total organic carbon remains unaccounted for after summing the carbon contribution from formate, oxalate, acetate, and glycolate from the IC and comparing to the results of the TOC analysis.

- $\mathrm{Cs}^{137}$ value from gamma counting shows a $22 \%$ difference with the value obtained from the ICP-MS. The $\mathrm{Tc}^{99}$ values from counting and the ICP-MS method show a difference of only $7 \%$.

- For the anion analysis (IC designator in the table) several analytes $\left(\mathrm{PO}_{4}{ }^{3-}, \mathrm{SO}_{4}{ }^{2-}\right.$, $\left.\mathrm{C}_{2} \mathrm{O}_{4}{ }^{2-}\right)$ were flagged for values less than $10 \mathrm{X}$ the detection limit.

- The $\%$ RSD for the ammonia analysis was slightly higher than the requirement of $15 \%$.

- Several of the elements from the ICP-ES analysis (B, Ba, Cd, Li, Ni, S, and V) were flagged for not meeting the required MRQ. The $\mathrm{Ce}$ and $\mathrm{Cr}$ results were flagged for being less than 10 times the detection limit.

- The result for $\mathrm{Hg}(<1.7 \mathrm{mg} / \mathrm{L})$ was flagged for not meeting the MRQ of $1.5 \mathrm{mg} / \mathrm{L}$.

- Results for glycolate and acetate were flagged for being less than 10 times the detection limit. The citrate was flagged for a low matrix spike recovery. However, as stated in the task plan, these analytes were provided as information only since there was insufficient method data to set QC parameters. The QC parameters were provided as target values.

- $\mathrm{Rb}$ and $\mathrm{Cs}^{133}$ values from the ICP-MS were flagged for high recoveries of the laboratory control standard although the matrix spike recoveries were within the required range.

- $\mathrm{Pa}^{231}$ was all flagged for not meeting the required MRQ.

- $\mathrm{The}^{\mathrm{Se}}{ }^{79}$ result was flagged for being less than 10 times the detection limits. Additionally, only a single result above the detection limits of the method was obtained.

- $\mathrm{U}^{238}$ result from the ICP-MS was flagged for the blank concentration being greater than $5 \%$ of the sample concentration. The $\mathrm{U}^{235}$ was flagged for the result being less than 10 times the detection limits.

- Gross alpha results were flagged for a \%RSD higher than the required $15 \%$. The results were also flagged for being less than 10 times the detection limits. 
WSRC-TR-2003-00379, REV. 0

SRT-RPP-2003-00181, REV. 0

\subsubsection{Discussion of Table 5-6, Comparison of the Un-Aged and Aged 7 M Diluted 241-AW-101 Sample}

- In general, the major components of the Un-Aged and Aged $7 \mathrm{M}$ diluted 241-AW-101 show a difference of less than $15 \%$ indicating no significant change in the sample composition with 6 months of aging.

- Fluoride results by IC show a $44 \%$ increase in the concentration from the un-aged to the aged $7 \mathrm{M}$ samples. An increase in the concentration could only occur by dissolution of fluoride from the solids. However, the analysis of the as-received 241-AW-101 solids did not find significant levels of fluoride present. ${ }^{1}$ The most probable explanation for the observed change in fluoride concentration is analytical error. The IC method suffers from poor resolution of the fluoride peak from other anions.

- $\quad$ TIC results show an increase of $42 \%$. Inorganic carbon is generally found as carbonate in supernate solutions. An increase in the TIC from the absorption of $\mathrm{CO}_{2}$ from the air would not be unexpected. The absorption of atmospheric $\mathrm{CO}_{2}$ is usually accompanied by a decrease in the free hydroxide concentration consumed in the formation of $\mathrm{CO}_{3}{ }^{-}$. However, the free hydroxide concentration also shows an increase of $23 \%$ from the un-aged to the aged $7 \mathrm{M}$ samples. Again, the most probable explanation for the observed change in concentration is analytical error.

- Cr concentration dropped by 50\% over the 6-month aging period. The apparent decrease in concentration may indicate precipitation of a small amount of chromium. However, it should be noted that the $\mathrm{Cr}$ concentration in these solutions are near detection limits.

- The $12 \mathrm{X}$ increase in $\mathrm{I}^{127}$ concentration after 6 months of aging would appear to be an artifact of the analysis. The $\mathrm{I}^{127}$ from ICP-MS suffers from memory effects and should be considered unreliable.

- The $44 \%$ decrease in the $\mathrm{Pu}^{239 / 240}$ concentration may indicate a slight amount of precipitation. The other $\mathrm{Pu}$ isotopes would be expected to show a similar decrease. The $\mathrm{Pu}^{238}$ also shows a decrease of $18 \%$ indicating that the decrease in $\mathrm{Pu}$ concentration may be real. However, the Pu concentrations are very low in these supernate solutions. Even thought he precision of the analyses are quite good, the results may be subject to significant errors in accuracy.

- Alpha counting results show a decrease of $79 \%$, however, the results are near detection limits, and therefore, subject to significant error.

- The weight percent dissolved solids of the Un-Aged $7 \mathrm{M}$ diluted 241-AW-101 appears to be low based on the density of $1.38 \mathrm{~g} / \mathrm{mL}$ and $7 \mathrm{M}$ sodium concentration of the solution. Based on past experience, a $7 \mathrm{M}$ sodium solution should have a weight percent dissolved solids of $\sim 40 \mathrm{wt} \%$. The discrepancy was not realized until the completion of the 6 month aging study at which point a re-analysis was not possible. 
- The weight percent insoluble solids of the Aged $7 \mathrm{M}$ sample were measured during the filtration of the entire aged sample. Although the sample has a very low insoluble solids content, the large volume of sample filtered produced enough solids to cause problems with the weight percent insoluble solids determination. Solids adhered to the side walls of the filtration apparatus and could not effectively be removed with the filter disc. Therefore, the values for both the weight percent insoluble solids were biased low.

\subsection{DATA TABLES}

Data in Tables 5-1 through 5-6 show the results of the characterization of the Un-Aged and Aged $7 \mathrm{M}$ diluted 241-AW-101 and include all replicates, blanks, standards, and matrix spike submitted with the samples. Cells left intentionally blank in the tables have been filled with a dash. 
WSRC-TR-2003-00379, REV. 0

SRT-RPP-2003-00181, REV. 0

Table 5-1. Abbreviations of Analytical Methods Used in Tables 5-2 through 5-6

\begin{tabular}{|l|c|c|}
\hline \multicolumn{1}{|c|}{ Analytical Method } & $\begin{array}{c}\text { Abbreviation } \\
\text { in Tables }\end{array}$ & $\begin{array}{c}\text { ADS } \\
\text { Procedure No. }\end{array}$ \\
\hline Ion Chromatography & IC & ADS-2306 \\
\hline Ammonia Purge and Trap & PT & ADS-2306 \\
\hline Titration & T & ADS-1206 Rev. 1 \\
\hline ICP-AES & IE & ADS-1564 \\
\hline ICP-MS & IM & ADS-1543 \\
\hline AA & AA & ADS-1554 Rev. 3 \\
\hline Calc. By Difference & Diff & NA \\
\hline Acidification & A & ADS-1206, Rev. 1 \\
\hline Gamma Spec. & GS & ADS-2420 \\
\hline Separation/Gamma Spec. & SG & ADS-2420 \\
\hline Separation/Alpha Spec. & SA & ADS-2453 \\
& & ADS-2449 \\
\hline Separation/Liquid Scintillation & SL & ADS-2447 \\
& & ADS-2444 \\
& & ADS-2407 \\
\hline Alpha Counting & AC 402 \\
\hline HPLC & HL & ADS-2660 \\
\hline GC-MS & GM & ADS-2661 \\
\hline
\end{tabular}


WSRC-TR-2003-00379, REV. 0

SRT-RPP-2003-00181, REV. 0

Table 5-2. Physical Properties of the Un-Aged 7 M Diluted 241-AW-101 Sample

\begin{tabular}{|l|c|c|c|c|c|c|c|}
\hline \multicolumn{1}{|c|}{ Property } & Units & $\begin{array}{c}\text { 1st } \\
\text { Replicate }\end{array}$ & $\begin{array}{c}\text { 2nd } \\
\text { Replicate }\end{array}$ & $\begin{array}{c}\text { 3rd } \\
\text { Replicate }\end{array}$ & Average & \%RSD & QC Flag \\
\hline $\begin{array}{l}\text { Density of Filtered } \\
\text { Supernate* }\end{array}$ & $\mathrm{g} / \mathrm{mL}$ & 1.43 & 1.41 & 1.43 & 1.42 & $0.8 \%$ & - \\
\hline Density of Slurry & $\mathrm{g} / \mathrm{mL}$ & 1.39 & 1.41 & 1.40 & 1.40 & $0.7 \%$ & - \\
\hline $\begin{array}{l}\text { Wt\% Vacuum Filtered } \\
\text { Solids }\end{array}$ & $\mathrm{Wt} \%$ & 0.74 & - & - & - & - & - \\
\hline $\mathrm{Wt} \%$ Dissolved Solids & $\mathrm{Wt} \%$ & $28.8^{* *}$ & $29.1^{* *}$ & $29.1^{* *}$ & $29.0^{* *}$ & $0.6 \%$ & - \\
\hline $\begin{array}{l}\mathrm{Wt} \% \text { Insoluble Solids } \\
\text { (measured) }\end{array}$ & $\mathrm{Wt} \%$ & 0.32 & - & - & - & - & - \\
\hline
\end{tabular}

* The density was measured at the ambient temperature of the Shielded Cells $\left(28^{\circ} \mathrm{C}\right)$.

** Result is obviously low based on density and sodium concentration. This discrepancy was not recognized until after the 6 month aging period so the measurement of the un-aged material could not be repeated.

QC Flags: none - meets all QC

$\mathrm{U}_{\mathrm{B}}$ - blank exceeds $5 \%$ of sample concentration

$\mathrm{U}_{\mathrm{E}}-$ value less than $10 \mathrm{x}$ the $\mathrm{DL}$

$$
\begin{aligned}
& U_{R} \text { - fails \%RSD criteria } \\
& U_{L} \text { - fails \% Recovery of LCS } \\
& \text { ND - not detected }
\end{aligned}
$$

$\mathrm{U}_{\mathrm{M}}$ - fails minimum MRQ criteria $\mathrm{U}_{\mathrm{S}}$ - fails \% Recovery of MS

N/A - not applicable

Table 5-3. Physical Properties of the Aged 7 M Diluted 241-AW-101 Sample

\begin{tabular}{|l|c|c|c|c|c|c|c|}
\hline \multicolumn{1}{|c|}{ Property } & Units & $\begin{array}{c}\text { 1st } \\
\text { Replicate }\end{array}$ & $\begin{array}{c}\text { 2nd } \\
\text { Replicate }\end{array}$ & $\begin{array}{c}\text { 3rd } \\
\text { Replicate }\end{array}$ & Average & \%RSD & $\begin{array}{c}\text { QC } \\
\text { Flag }\end{array}$ \\
\hline Density of Filtered Supernate* & $\mathrm{g} / \mathrm{mL}$ & 1.39 & 1.38 & 1.38 & 1.38 & $0.4 \%$ & - \\
\hline $\mathrm{Wt} \%$ Vacuum Filtered Solids & $\mathrm{Wt} \%$ & $0.25^{* *}$ & - & - & - & - & - \\
\hline $\mathrm{Wt} \%$ Dissolved Solids & $\mathrm{Wt} \%$ & 43.2 & 42.1 & 43.9 & 43.1 & $2.1 \%$ & - \\
\hline $\begin{array}{l}\text { Wt\% Insoluble Solids } \\
\text { (measured) }\end{array}$ & $\mathrm{Wt} \%$ & $0.14 * *$ & - & - & - & - & - \\
\hline
\end{tabular}

* The density was measured at the ambient temperature of the Shielded Cells $\left(22^{\circ} \mathrm{C}\right)$.

** Result is biased low due to adhesion of solids to filtration apparatus.

QC Flags: none - meets all QC

$\mathrm{U}_{\mathrm{B}}$ - blank exceeds $5 \%$ of sample concentration

$\mathrm{U}_{\mathrm{E}}$ - value less than $10 \mathrm{x}$ the $\mathrm{DL}$
$\mathrm{U}_{\mathrm{R}}$ - fails \%RSD criteria

$\mathrm{U}_{\mathrm{L}}$ - fails \% Recovery of LCS

ND - not detected
$\mathrm{U}_{\mathrm{M}}$ - fails minimum MRQ criteria

$\mathrm{U}_{\mathrm{S}}$ - fails \% Recovery of MS

N/A - not applicable 
WSRC-TR-2003-00379, REV. 0

SRT-RPP-2003-00181, REV. 0

Table 5-4. Composition of the Un-Aged 7 M Diluted 241-AW-101 Sample

\begin{tabular}{|c|c|c|c|c|c|c|c|c|c|}
\hline Analyte & $\begin{array}{c}\text { 1st } \\
\text { Replicate } \\
\text { (mg/L) }\end{array}$ & $\begin{array}{c}\text { 2nd } \\
\text { Replicate } \\
\text { (mg/L) }\end{array}$ & $\begin{array}{c}\text { 3rd } \\
\text { Replicate } \\
(\mathrm{mg} / \mathrm{L})\end{array}$ & $\begin{array}{c}\text { Average } \\
(\mathrm{mg} / \mathrm{L})\end{array}$ & $\%$ RSD & $\begin{array}{c}\text { Blank } \\
(\mathrm{mg} / \mathrm{L})\end{array}$ & $\begin{array}{c}\text { LCS \% } \\
\text { Recovery }\end{array}$ & $\begin{array}{c}\text { MS \% } \\
\text { Recovery }\end{array}$ & $\begin{array}{c}\text { QC } \\
\text { Flag }\end{array}$ \\
\hline $\mathrm{NO}_{3}^{-}$(IC) & $1.05 \mathrm{E}+05$ & $1.06 \mathrm{E}+05$ & $1.08 \mathrm{E}+05$ & $1.06 \mathrm{E}+05$ & $1.3 \%$ & $<2.0 \mathrm{E}+02$ & $98 \%$ & $96 \%$ & - \\
\hline $\mathrm{NO}_{2}^{-}$(IC) & $6.25 \mathrm{E}+04$ & $6.47 \mathrm{E}+04$ & $6.36 \mathrm{E}+04$ & $6.36 \mathrm{E}+04$ & $1.8 \%$ & $<2.0 \mathrm{E}+02$ & $100 \%$ & $97 \%$ & - \\
\hline $\mathrm{PO}_{4}{ }^{3-}(\mathrm{IC})$ & $3.19 \mathrm{E}+02$ & $2.78 \mathrm{E}+02$ & $2.77 \mathrm{E}+02$ & $2.92 \mathrm{E}+02$ & $8.3 \%$ & $<2.0 \mathrm{E}+02$ & $100 \%$ & $97 \%$ & $\mathrm{U}_{\mathrm{E}}$ \\
\hline $\mathrm{SO}_{4}{ }^{2-}$ (IC) & $2.20 \mathrm{E}+02$ & $1.79 \mathrm{E}+02$ & $1.78 \mathrm{E}+02$ & $1.92 \mathrm{E}+02$ & $12 \%$ & $<1.0 \mathrm{E}+02$ & $98 \%$ & $96 \%$ & $\mathrm{U}_{\mathrm{E}}$ \\
\hline $\mathrm{C}_{2} \mathrm{O}_{4}{ }^{2-}(\mathrm{IC})$ & $2.00 \mathrm{E}+02$ & $1.79 \mathrm{E}+02$ & $1.58 \mathrm{E}+02$ & $1.79 \mathrm{E}+02$ & $12 \%$ & $<2.0 \mathrm{E}+02$ & $98 \%$ & $96 \%$ & $\mathrm{U}_{\mathrm{E}}$ \\
\hline $\mathrm{Cl}^{-}$(IC) & $3.81 \mathrm{E}+03$ & $3.46 \mathrm{E}+03$ & $3.39 \mathrm{E}+03$ & $3.55 \mathrm{E}+03$ & $6.4 \%$ & $<4.0 \mathrm{E}+01$ & $99 \%$ & $96 \%$ & - \\
\hline $\mathrm{F}^{-}$(IC) & $3.19 \mathrm{E}+02$ & $2.98 \mathrm{E}+02$ & $3.17 \mathrm{E}+02$ & $3.11 \mathrm{E}+02$ & $3.8 \%$ & $<4.0 \mathrm{E}+01$ & $103 \%$ & $99 \%$ & $\mathrm{U}_{\mathrm{E}}$ \\
\hline $\mathrm{CHO}_{2}^{-}$(IC) & $1.76 \mathrm{E}+03$ & $1.61 \mathrm{E}+03$ & $1.56 \mathrm{E}+03$ & $1.64 \mathrm{E}+03$ & $6.1 \%$ & $<2.0 \mathrm{E}+02$ & $99 \%$ & $98 \%$ & $\mathrm{U}_{\mathrm{E}}$ \\
\hline $\mathrm{NH}_{4}^{+}(\mathrm{PT})$ & $<1.0 \mathrm{E}+02$ & $<9.9 \mathrm{E}+01$ & $<9.9 \mathrm{E}+01$ & $<9.9 \mathrm{E}+01$ & - & $<1.0 \mathrm{E}+02$ & $106 \%$ & $94 \%$ & - \\
\hline $\mathrm{OH}_{\text {free }}^{-}(\mathrm{T})$ & $4.17 \mathrm{E}+04$ & $4.19 \mathrm{E}+04$ & $4.07 \mathrm{E}+04$ & $4.14 \mathrm{E}+04$ & $1.5 \%$ & $<6.8 \mathrm{E}+02$ & N/A & N/A & - \\
\hline $\mathrm{OH}_{\text {total }}^{-}(\mathrm{T})$ & $5.87 \mathrm{E}+04$ & $5.87 \mathrm{E}+04$ & $5.79 \mathrm{E}+04$ & $5.84 \mathrm{E}+04$ & $0.8 \%$ & $<6.8 \mathrm{E}+02$ & $103 \%$ & N/A & - \\
\hline TIC (A) & $8.42 \mathrm{E}+02$ & $7.77 \mathrm{E}+02$ & $7.64 \mathrm{E}+02$ & $7.94 \mathrm{E}+02$ & $5.3 \%$ & $1.99 \mathrm{E}-02$ & $101 \%$ & $117 \%$ & - \\
\hline TOC (Diff) & $1.67 \mathrm{E}+03$ & $1.69 \mathrm{E}+03$ & $1.53 \mathrm{E}+03$ & $1.63 \mathrm{E}+03$ & $5.2 \%$ & $1.41 \mathrm{E}+02$ & $97 \%$ & $79 \%$ & - \\
\hline $\mathrm{Al}$ (IE) & $1.87 \mathrm{E}+04$ & $1.86 \mathrm{E}+04$ & $1.86 \mathrm{E}+04$ & $1.86 \mathrm{E}+04$ & $0.3 \%$ & $<1.4 \mathrm{E}+01$ & $99 \%$ & N/A & - \\
\hline B (IE) & $2.17 \mathrm{E}+01$ & $2.14 \mathrm{E}+01$ & $2.19 \mathrm{E}+01$ & $2.17 \mathrm{E}+01$ & $1.2 \%$ & $<6.8 \mathrm{E}+00$ & $99 \%$ & N/A & - \\
\hline $\mathrm{Ba}$ (IE) & $1.92 \mathrm{E}+00$ & $1.81 \mathrm{E}+00$ & $1.86 \mathrm{E}+00$ & $1.86 \mathrm{E}+00$ & $3.0 \%$ & $<1.5 \mathrm{E}+00$ & $99 \%$ & $103 \%$ & - \\
\hline $\mathrm{Ca}$ (IE) & $<5.8 \mathrm{E}+00$ & $<5.6 \mathrm{E}+00$ & $<5.6 \mathrm{E}+00$ & $<5.6 \mathrm{E}+00$ & - & $<5.5 \mathrm{E}+00$ & $101 \%$ & $96 \%$ & $\mathrm{U}_{\mathrm{E}}$ \\
\hline Cd (IE) & $1.88 \mathrm{E}+00$ & $1.97 \mathrm{E}+00$ & $1.72 \mathrm{E}+00$ & $1.86 \mathrm{E}+00$ & $6.8 \%$ & $<1.0 \mathrm{E}+00$ & $99 \%$ & $98 \%$ & - \\
\hline $\mathrm{Cr}$ (IE & $6.41 \mathrm{E}+01$ & $6.38 \mathrm{E}+01$ & $6.33 \mathrm{E}+01$ & $6.37 \mathrm{E}+01$ & $0.6 \%$ & $<1.4 \mathrm{E}+00$ & $100 \%$ & $97 \%$ & - \\
\hline $\mathrm{Fe}$ (IE) & $2.82 \mathrm{E}+00$ & $2.83 \mathrm{E}+00$ & $2.82 \mathrm{E}+00$ & $2.82 \mathrm{E}+00$ & $0.2 \%$ & $<8.6 \mathrm{E}-01$ & $101 \%$ & $95 \%$ & - \\
\hline $\mathrm{La}$ (IE) & $2.38 \mathrm{E}+00$ & $2.14 \mathrm{E}+00$ & $2.45 \mathrm{E}+00$ & $2.32 \mathrm{E}+00$ & $7.0 \%$ & $<1.7 \mathrm{E}+00$ & $99 \%$ & N/A & - \\
\hline $\mathrm{Li}$ (IE) & $<1.1 \mathrm{E}+01$ & $<1.0 \mathrm{E}+01$ & $<1.0 \mathrm{E}+01$ & $<1.1 \mathrm{E}+01$ & - & $<1.0 \mathrm{E}+01$ & $105 \%$ & N/A & $\mathrm{U}_{\mathrm{M}}$ \\
\hline $\mathrm{Mg}$ (IE) & $<1.3 \mathrm{E}+00$ & $<1.3 \mathrm{E}+00$ & $<1.3 \mathrm{E}+00$ & $<1.3 \mathrm{E}+00$ & - & $<1.3 \mathrm{E}+00$ & $100 \%$ & N/A & - \\
\hline $\mathrm{Na}$ (IE) & $1.68 \mathrm{E}+05$ & $1.70 \mathrm{E}+05$ & $1.73 \mathrm{E}+05$ & $1.70 \mathrm{E}+05$ & $1.5 \%$ & $<4.4 \mathrm{E}+01$ & $103 \%$ & $107 \%$ & - \\
\hline $\mathrm{Ni}$ (IE) & $3.44 \mathrm{E}+00$ & $3.73 E+00$ & $3.95 \mathrm{E}+00$ & $3.71 \mathrm{E}+00$ & $6.9 \%$ & $<3.3 \mathrm{E}+00$ & $100 \%$ & $95 \%$ & - \\
\hline $\mathrm{P}$ (IE) & $2.21 \mathrm{E}+02$ & $2.20 \mathrm{E}+02$ & $2.21 \mathrm{E}+02$ & $2.21 \mathrm{E}+02$ & $0.3 \%$ & $<1.7 \mathrm{E}+01$ & $99 \%$ & N/A & - \\
\hline
\end{tabular}

*Single value

** Average of two replicates

QC Flags: none - meets all QC

$\mathrm{U}_{\mathrm{B}}$ - blank exceeds $5 \%$ of sample concentration

$\mathrm{U}_{\mathrm{R}}$ - fails \%RSD criteria

$\mathrm{U}_{\mathrm{M}}$ - fails minimum MRQ criteria

$\mathrm{U}_{\mathrm{E}}$ - value less than 10x the DL

$\mathrm{U}_{\mathrm{L}}$ - fails \% Recovery of LCS

ND - not detected
$\mathrm{U}_{\mathrm{S}}$ - fails \% Recovery of MS

N/A - not applicable 
WSRC-TR-2003-00379, REV. 0 SRT-RPP-2003-00181, REV. 0

Table 5-4. Composition of the Un-Aged 7 M Diluted 241-AW-101 Sample - continued

\begin{tabular}{|c|c|c|c|c|c|c|c|c|c|}
\hline Analyte & $\begin{array}{c}\text { 1st } \\
\text { Replicate } \\
\text { (mg/L) }\end{array}$ & $\begin{array}{c}\text { 2nd } \\
\text { Replicate } \\
\text { (mg/L) }\end{array}$ & $\begin{array}{c}\text { 3rd } \\
\text { Replicate } \\
(\mathbf{m g} / \mathbf{L})\end{array}$ & $\begin{array}{c}\text { Average } \\
(\mathrm{mg} / \mathrm{L})\end{array}$ & $\%$ RSD & $\begin{array}{c}\text { Blank } \\
\text { (mg/L) }\end{array}$ & $\begin{array}{c}\text { LCS \% } \\
\text { Recovery }\end{array}$ & $\begin{array}{c}\text { MS \% } \\
\text { Recovery }\end{array}$ & $\begin{array}{c}\text { QC } \\
\text { Flag }\end{array}$ \\
\hline $\mathrm{Pb}$ (IE) & $\mathrm{E}+01$ & $2.85 \mathrm{E}+01$ & $2.95 \mathrm{E}+01$ & $92 \mathrm{E}+01$ & $\%$ & $<7.7 \mathrm{E}+00$ & $99 \%$ & N/A & - \\
\hline $\mathrm{U}$ (IE) & $<1.3 \mathrm{E}+02$ & $<1.2 \mathrm{E}+02$ & $<1.2 \mathrm{E}+02$ & $<1.2 \mathrm{E}+02$ & - & $<1.2 \mathrm{E}+02$ & $101 \%$ & N/A & $\mathrm{U}_{\mathrm{E}}$ \\
\hline $\mathrm{K}(\mathrm{IE})$ & $3.14 \mathrm{E}+04$ & $3.12 \mathrm{E}+04$ & $3.13 \mathrm{E}+04$ & $3.13 \mathrm{E}+04$ & $0.3 \%$ & $<2.3 \mathrm{E}+02$ & $103 \%$ & N/A & - \\
\hline $\mathrm{S}$ (IE) & $2.50 \mathrm{E}+02$ & $2.58 \mathrm{E}+02$ & $2.68 \mathrm{E}+02$ & $2.59 \mathrm{E}+02$ & $3.5 \%$ & $<5.8 \mathrm{E}+00$ & $101 \%$ & N/A & - \\
\hline $\mathrm{Ce}$ (IE) & $<6.8 \mathrm{E}+00$ & $<6.5 \mathrm{E}+00$ & $<6.5 \mathrm{E}+00$ & $<6.6 \mathrm{E}+00$ & - & $<6.5 \mathrm{E}+00$ & $99 \%$ & N/A & $\mathrm{U}_{\mathrm{M}}$ \\
\hline $\mathrm{V}$ (IE) & $<5.0 \mathrm{E}-01$ & $<4.8 \mathrm{E}-01$ & $<4.8 \mathrm{E}-01$ & $<4.9 \mathrm{E}-01$ & - & $<4.8 \mathrm{E}-01$ & $100 \%$ & N/A & - \\
\hline $\mathrm{Na}(\mathrm{AA})$ & $1.57 \mathrm{E}+05$ & $1.53 \mathrm{E}+05$ & $1.52 \mathrm{E}+05$ & $1.54 \mathrm{E}+05$ & $1.5 \%$ & $<1.9 \mathrm{E}+03$ & $98 \%$ & $96 \%$ & - \\
\hline $\mathrm{K}(\mathrm{AA})$ & $2.98 \mathrm{E}+04$ & $2.90 \mathrm{E}+04$ & $2.93 \mathrm{E}+04$ & $2.93 \mathrm{E}+04$ & $1.4 \%$ & $5.46 \mathrm{E}+01$ & $104 \%$ & $94 \%$ & - \\
\hline $\mathrm{Hg}(\mathrm{AA})$ & $<2.3 \mathrm{E}+00$ & $<2.2 \mathrm{E}+00$ & $<2.2 \mathrm{E}+00$ & $<2.2 \mathrm{E}+00$ & - & $<1.1 \mathrm{E}-01$ & $95 \%$ & $88 \%$ & $\mathrm{U}_{\mathrm{M}}$ \\
\hline Citrate (IC) & $<2.0 \mathrm{E}+02$ & $<2.0 \mathrm{E}+02$ & $<2.0 \mathrm{E}+02$ & $<2.0 \mathrm{E}+02$ & - & $<2.0 \mathrm{E}+02$ & $102 \%$ & $6 \%$ & $\mathrm{U}_{\mathrm{M}} \mathrm{U}_{\mathrm{S}}$ \\
\hline Glycolate (IC) & $3.99 \mathrm{E}+02$ & $3.97 \mathrm{E}+02$ & $3.96 \mathrm{E}+02$ & $3.97 \mathrm{E}+02$ & $0.4 \%$ & $<2.0 \mathrm{E}+02$ & $101 \%$ & $94 \%$ & - \\
\hline Acetate (IC) & $1.22 \mathrm{E}+03$ & $1.21 \mathrm{E}+03$ & $1.21 \mathrm{E}+03$ & $1.21 \mathrm{E}+03$ & $0.4 \%$ & 02 & 96 & 99 & - \\
\hline EDTA (HL) & $<2.0 \mathrm{E}+02$ & $<2.0 \mathrm{E}+02$ & $<2.0 \mathrm{E}+02$ & $<2.0 \mathrm{E}+02$ & - & $<2.0 \mathrm{E}+02$ & $100 \%$ & $105 \%$ & $\mathrm{U}_{\mathrm{M}}$ \\
\hline HEDTA (HL) & $<2.0 \mathrm{E}+02$ & $<2.0 \mathrm{E}+02$ & $<2.0 \mathrm{E}+02$ & $<2.0 \mathrm{E}+02$ & - & $<2.0 \mathrm{E}+02$ & $100 \%$ & $92 \%$ & $\mathrm{U}_{\mathrm{M}}$ \\
\hline IDA (GM) & $<1.0 \mathrm{E}+03$ & $<9.9 \mathrm{E}+02$ & $<9.9 \mathrm{E}+02$ & $<9.9 \mathrm{E}+02$ & - & $<1.0 \mathrm{E}+03$ & $86 \%$ & $116 \%$ & - \\
\hline NTA (GM) & $<1.0 \mathrm{E}+03$ & $<9.9 \mathrm{E}+02$ & $<9.9 \mathrm{E}+02$ & $<9.9 \mathrm{E}+02$ & - & $<1.0 \mathrm{E}+03$ & $86 \%$ & $116 \%$ & - \\
\hline ED3A (GM) & ND & ND & ND & - & - & ND & $86 \%$ & $116 \%$ & - \\
\hline $\mathrm{Rb}$ (IM) & $6.22 \mathrm{E}+00$ & $6.39 \mathrm{E}+00$ & $6.60 \mathrm{E}+00$ & $6.40 \mathrm{E}+00$ & $2.9 \%$ & $7.02 \mathrm{E}-03$ & $101 \%$ & - & - \\
\hline W (IM) & $7.68 \mathrm{E}+01$ & $7.03 \mathrm{E}+01$ & $6.93 \mathrm{E}+01$ & $7.21 \mathrm{E}+01$ & $5.6 \%$ & 8.3 & - & $134 \%$ & $\mathrm{U}_{\mathrm{s}}$ \\
\hline Th (IM) & $2.97 \mathrm{E}-02$ & $2.74 \mathrm{E}-02$ & $2.52 \mathrm{E}-02$ & $2.74 \mathrm{E}-02$ & $8.2 \%$ & $<3.8 \mathrm{E}-03$ & $98 \%$ & $99 \%$ & - \\
\hline $\mathrm{I}^{127}$ (IM) & $1.03 \mathrm{E}+00$ & $1.17 \mathrm{E}+00$ & $1.20 \mathrm{E}+00$ & $1.13 \mathrm{E}+00$ & $8.1 \%$ & $2.01 \mathrm{E}-01$ & - & $140 \%$ & $\mathrm{U}_{\mathrm{B}} \mathrm{U}_{\mathrm{S}}$ \\
\hline $\mathrm{Cs}^{133}$ (IM) & $9.75 \mathrm{E}+00$ & $1.06 \mathrm{E}+01$ & $1.11 \mathrm{E}+01$ & $1.05 \mathrm{E}+01$ & $6.5 \%$ & $8.41 \mathrm{E}-03$ & $111 \%$ & $107 \%$ & - \\
\hline $\mathrm{Cs}^{135}$ (IM) & $2.11 \mathrm{E}+00$ & $2.24 \mathrm{E}+00$ & $2.36 \mathrm{E}+00$ & $2.24 \mathrm{E}+00$ & $5.6 \%$ & $<1.6 \mathrm{E}-03$ & $101 \%$ & $107 \%$ & - \\
\hline $\mathrm{Cs}^{137}$ (IM) & $2.98 \mathrm{E}+00$ & $3.20 \mathrm{E}+00$ & $3.35 \mathrm{E}+00$ & $3.18 \mathrm{E}+00$ & $5.8 \%$ & $<1.4 \mathrm{E}-02$ & $99 \%$ & $104 \%$ & - \\
\hline
\end{tabular}

* Single value

** Average of two replicates

QC Flags: none - meets all QC

$\mathrm{U}_{\mathrm{B}}$ - blank exceeds $5 \%$ of sample concentration

$\mathrm{U}_{\mathrm{E}}$ - value less than $10 \mathrm{x}$ the $\mathrm{DL}$

$\mathrm{U}_{\mathrm{R}}$ - fails $\% \mathrm{RSD}$ criteria

$\mathrm{U}_{\mathrm{L}}$ - fails \% Recovery of LCS

ND - not detected
$\mathrm{U}_{\mathrm{M}}$ - fails minimum MRQ criteria

$\mathrm{U}_{\mathrm{S}}$ - fails \% Recovery of MS

N/A - not applicable 
WSRC-TR-2003-00379, REV. 0

SRT-RPP-2003-00181, REV. 0

Table 5-4. Composition of the Un-Aged 7 M Diluted 241-AW-101 Sample - continued

\begin{tabular}{|c|c|c|c|c|c|c|c|c|c|}
\hline Analyte & $\begin{array}{c}\text { 1st } \\
\text { Replicate } \\
(\mathbf{m C i} / \mathrm{L})\end{array}$ & $\begin{array}{c}\text { 2nd } \\
\text { Replicate } \\
(\mathbf{m C i} / \mathbf{L})\end{array}$ & $\begin{array}{c}\text { 3rd } \\
\text { Replicate } \\
(\mathbf{m C i} / \mathbf{L})\end{array}$ & $\begin{array}{l}\text { Average } \\
(\mathrm{mCi} / \mathbf{L})\end{array}$ & $\%$ RSD & $\begin{array}{c}\text { Blank } \\
(\mathbf{m C i} / \mathbf{L})\end{array}$ & $\left|\begin{array}{cc}\text { LCS } & \% \\
\text { Recovery }\end{array}\right|$ & $\begin{array}{c}\text { MS \% } \\
\text { Recovery }\end{array}$ & $\begin{array}{c}\text { QC } \\
\text { Flag }\end{array}$ \\
\hline $\mathrm{Cs}^{137}(\mathrm{GS})$ & $2.58 \mathrm{E}+02$ & $2.58 \mathrm{E}+02$ & $2.55 \mathrm{E}+02$ & $2.57 \mathrm{E}+02$ & $0.7 \%$ & $<2.5 \mathrm{E}-02$ & $\mathrm{~N} / \mathrm{A}$ & $\mathrm{N} / \mathrm{A}$ & - \\
\hline $\mathrm{Eu}^{154}(\mathrm{GS})$ & $<6.5 \mathrm{E}-01$ & $<3.7 \mathrm{E}-01$ & $<8.1 \mathrm{E}-01$ & $<6.1 \mathrm{E}-01$ & - & $<2.2 \mathrm{E}-02$ & $\mathrm{~N} / \mathrm{A}$ & $\mathrm{N} / \mathrm{A}$ & $\mathrm{U}_{\mathrm{M}}$ \\
\hline $\mathrm{Eu}^{155}(\mathrm{GS})$ & $<1.6 \mathrm{E}+00$ & $<1.6 \mathrm{E}+00$ & $<1.5 \mathrm{E}+00$ & $<1.5 \mathrm{E}+00$ & - & $<3.2 \mathrm{E}-02$ & $\mathrm{~N} / \mathrm{A}$ & N/A & $\mathrm{U}_{\mathrm{M}}$ \\
\hline $\mathrm{Co}^{60}(\mathrm{GS})$ & $<1.9 \mathrm{E}-01$ & $<6.5 \mathrm{E}-02$ & $<2.2 \mathrm{E}-01$ & $<1.6 \mathrm{E}-01$ & - & $<2.2 \mathrm{E}-02$ & N/A & N/A & $\mathrm{U}_{\mathrm{M}}$ \\
\hline $\mathrm{Sn}^{126}(\mathrm{GS})$ & $<1.4 \mathrm{E}+00$ & $<1.4 \mathrm{E}+00$ & $<1.3 \mathrm{E}+00$ & $<1.4 \mathrm{E}+00$ & - & $<2.5 \mathrm{E}-02$ & N/A & N/A & $\mathrm{U}_{\mathrm{M}}$ \\
\hline $\mathrm{Pa}^{231}(\mathrm{GS})$ & $<3.1 \mathrm{E}+01$ & $<3.0 \mathrm{E}+01$ & $<2.9 \mathrm{E}+01$ & $<3.0 \mathrm{E}+01$ & - & $<4.7 \mathrm{E}-01$ & N/A & N/A & $\mathrm{U}_{\mathrm{M}}$ \\
\hline $\mathrm{Sr}^{90}(\mathrm{SL})$ & $6.17 \mathrm{E}-02$ & $6.43 \mathrm{E}-02$ & $6.36 \mathrm{E}-02$ & $6.32 \mathrm{E}-02$ & $2 \%$ & $<1.8 \mathrm{E}-02$ & $104 \%$ & $104 \%$ & - \\
\hline $\mathrm{Se}^{79}(\mathrm{SL})$ & Not & Analyzed & - & - & - & - & - & - & - \\
\hline $\mathrm{H}^{3}(\mathrm{SL})$ & $<1.1 \mathrm{E}-02$ & $<1.0 \mathrm{E}-02$ & $<2.2 \mathrm{E}-02$ & $<1.4 \mathrm{E}-02$ & - & $<1.0 \mathrm{E}-02$ & $96 \%$ & $112 \%$ & - \\
\hline $\mathrm{C}^{14}(\mathrm{SL})$ & $6.68 \mathrm{E}-04$ & $<5.0 \mathrm{E}-04$ & 7.69E-04 & $7.18 \mathrm{E}-04 * *$ & $10 \%$ & $<5.0 \mathrm{E}-04$ & $108 \%$ & $115 \%$ & $\mathrm{U}_{\mathrm{E}}$ \\
\hline $\mathrm{Tc}^{99}{ }_{\text {pertech }}(\mathrm{SL})$ & $1.10 \mathrm{E}-01$ & $1.15 \mathrm{E}-01$ & $1.11 \mathrm{E}-01$ & $1.12 \mathrm{E}-01$ & $2.7 \%$ & $5.57 \mathrm{E}-04$ & $\mathrm{~N} / \mathrm{A}$ & $\mathrm{N} / \mathrm{A}$ & - \\
\hline $\mathrm{I}^{129}(\mathrm{SG})$ & $1.77 \mathrm{E}-04$ & $2.04 \mathrm{E}-04$ & $1.63 \mathrm{E}-04$ & $1.81 \mathrm{E}-04$ & $11 \%$ & $<3.3 \mathrm{E}-06$ & N/A & $\mathrm{N} / \mathrm{A}$ & - \\
\hline $\mathrm{Pu}^{238}(\mathrm{SA})$ & $6.90 \mathrm{E}-04$ & $9.79 \mathrm{E}-04$ & $6.24 \mathrm{E}-04$ & 7.64E-04 & $25 \%$ & $<3.6 \mathrm{E}-05$ & $\mathrm{~N} / \mathrm{A}$ & N/A & $\mathrm{U}_{\mathrm{R}}$ \\
\hline $\mathrm{Pu}^{239 / 240}(\mathrm{SA})$ & $2.29 \mathrm{E}-04$ & $2.11 \mathrm{E}-04$ & $1.72 \mathrm{E}-04$ & 2.04E-04 & $14 \%$ & $<1.7 \mathrm{E}-05$ & $\mathrm{~N} / \mathrm{A}$ & $\mathrm{N} / \mathrm{A}$ & - \\
\hline $\mathrm{Pu}^{241}(\mathrm{SA})$ & $<7.5 \mathrm{E}-04$ & $<1.3 \mathrm{E}-03$ & $<7.8 \mathrm{E}-04$ & $<9.5 \mathrm{E}-04$ & - & $<7.2 \mathrm{E}-04$ & N/A & N/A & - \\
\hline $\mathrm{Am}^{241}(\mathrm{SG})$ & $<6.8 \mathrm{E}-04$ & $<9.1 \mathrm{E}-04$ & $4.86 \mathrm{E}-04$ & $4.86 \mathrm{E}-04 *$ & - & $<4.1 \mathrm{E}-04$ & N/A & $\mathrm{N} / \mathrm{A}$ & - \\
\hline $\mathrm{Cm}^{242}(\mathrm{SA})$ & $<5.5 \mathrm{E}-06$ & $<8.5 \mathrm{E}-06$ & $<6.7 \mathrm{E}-06$ & $<6.9 \mathrm{E}-06$ & - & $<9.1 \mathrm{E}-06$ & $\mathrm{~N} / \mathrm{A}$ & $\mathrm{N} / \mathrm{A}$ & - \\
\hline $\mathrm{Cm}^{243 / 244}(\mathrm{SA})$ & $3.61 \mathrm{E}-04$ & 7.93E-04 & $7.58 \mathrm{E}-04$ & 6.37E-04 & $38 \%$ & $3.84 \mathrm{E}-04$ & N/A & N/A & $\mathrm{U}_{\mathrm{B}} \mathrm{U}_{\mathrm{R}}$ \\
\hline $\mathrm{Tc}^{99}$ total (IM) & $9.93 \mathrm{E}-02$ & $9.64 \mathrm{E}-02$ & $9.63 \mathrm{E}-02$ & $9.73 \mathrm{E}-02$ & $1.8 \%$ & $3.90 \mathrm{E}-05$ & $101 \%$ & $118 \%$ & - \\
\hline $\mathrm{Np}^{237}$ (IM) & $<2.8 \mathrm{E}-06$ & $<2.7 \mathrm{E}-06$ & $<2.7 \mathrm{E}-06$ & $<2.7 \mathrm{E}-06$ & - & $<2.7 \mathrm{E}-06$ & - & - & - \\
\hline $\mathrm{Pu}^{239}$ (IM) & $4.25 \mathrm{E}-04$ & $4.41 \mathrm{E}-04$ & $4.55 \mathrm{E}-04$ & $4.41 \mathrm{E}-04$ & $3.5 \%$ & $<2.3 \mathrm{E}-04$ & - & - & $\mathrm{U}_{\mathrm{E}}$ \\
\hline $\mathrm{Pu}^{240}$ (IM) & $<9.0 \mathrm{E}-04$ & $<8.6 \mathrm{E}-04$ & $<8.6 \mathrm{E}-04$ & $<8.7 \mathrm{E}-04$ & - & $<8.6 \mathrm{E}-04$ & - & - & - \\
\hline $\mathrm{U}^{233}(\mathrm{IM})$ & $<3.8 \mathrm{E}-05$ & $<3.7 \mathrm{E}-05$ & $<3.7 \mathrm{E}-05$ & $<3.7 \mathrm{E}-05$ & - & $<3.7 \mathrm{E}-05$ & - & - & - \\
\hline $\mathrm{U}^{234}(\mathrm{IM})$ & $<2.5 \mathrm{E}-05$ & $<2.4 \mathrm{E}-05$ & $<2.4 \mathrm{E}-05$ & $<2.4 \mathrm{E}-05$ & - & $<2.4 \mathrm{E}-05$ & - & - & - \\
\hline
\end{tabular}

* Single value

** Average of two replicates

QC Flags: none - meets all QC

$\mathrm{U}_{\mathrm{B}}$ - blank exceeds $5 \%$ of sample concentration

$\mathrm{U}_{\mathrm{E}}$ - value less than $10 \mathrm{x}$ the $\mathrm{DL}$

$\mathrm{U}_{\mathrm{R}}$ - fails $\% \mathrm{RSD}$ criteria

$\mathrm{U}_{\mathrm{L}}$ - fails \% Recovery of LCS

ND - not detected
$\mathrm{U}_{\mathrm{M}}$ - fails minimum MRQ criteria

$\mathrm{U}_{\mathrm{S}}$ - fails \% Recovery of MS

N/A - not applicable 
WSRC-TR-2003-00379, REV. 0

SRT-RPP-2003-00181, REV. 0

Table 5-4. Composition of the Un-Aged 7 M Diluted 241-AW-101 Sample - continued

\begin{tabular}{|l|c|c|c|c|c|c|c|c|c|}
\hline \multicolumn{1}{|c|}{ Analyte } & $\begin{array}{c}\mathbf{1 s t} \\
\text { Replicate } \\
(\mathbf{m C i} / \mathbf{L})\end{array}$ & $\begin{array}{c}\mathbf{2 n d} \\
\text { Replicate } \\
(\mathbf{m C i} / \mathbf{L})\end{array}$ & $\begin{array}{c}\text { 3rd } \\
\text { Replicate } \\
(\mathbf{m C i} / \mathbf{L})\end{array}$ & $\begin{array}{c}\text { Average } \\
(\mathbf{m C i} / \mathbf{L})\end{array}$ & $\mathbf{\% R S D}$ & $\begin{array}{c}\text { Blank } \\
(\mathbf{m C i} / \mathbf{L})\end{array}$ & $\begin{array}{c}\text { LCS \% } \\
\text { Recovery }\end{array}$ & $\begin{array}{c}\text { MS \% } \\
\text { Recovery }\end{array}$ & $\begin{array}{c}\text { QC } \\
\text { Flag }\end{array}$ \\
\hline $\mathrm{U}^{235}(\mathrm{IM})$ & $3.18 \mathrm{E}-08$ & $3.52 \mathrm{E}-08$ & $3.43 \mathrm{E}-08$ & $3.38 \mathrm{E}-08$ & $5.2 \%$ & $<8.2 \mathrm{E}-09$ & - & - & $\mathrm{U}_{\mathrm{E}}$ \\
\hline $\mathrm{U}^{236}(\mathrm{IM})$ & $<2.6 \mathrm{E}-07$ & $<2.5 \mathrm{E}-07$ & $<2.5 \mathrm{E}-07$ & $<2.5 \mathrm{E}-07$ & - & $<2.5 \mathrm{E}-07$ & - & - & - \\
\hline $\mathrm{U}^{238}(\mathrm{IM})$ & $6.17 \mathrm{E}-07$ & $5.93 \mathrm{E}-07$ & $5.76 \mathrm{E}-07$ & $5.95 \mathrm{E}-07$ & $3.4 \%$ & $1.83 \mathrm{E}-09$ & $102 \%$ & $99 \%$ & - \\
\hline Alpha (AC) & $1.89 \mathrm{E}-02$ & $2.60 \mathrm{E}-02$ & - & $2.25 \mathrm{E}-02 * *$ & $22 \%$ & $4.55 \mathrm{E}-04$ & $103 \%$ & $108 \%$ & $\mathrm{U}_{\mathrm{E}} \mathrm{U}_{\mathrm{R}}$ \\
\hline $\mathrm{Alpha}_{\mathrm{sum}}$ & - & - & - & $1.45 \mathrm{E}-03 *$ & - & $<2.3 \mathrm{E}-05$ & $\mathrm{~N} / \mathrm{A}$ & $\mathrm{N} / \mathrm{A}$ & - \\
\hline
\end{tabular}

* Single value

** Average of two replicates

QC Flags: none - meets all QC

$\mathrm{U}_{\mathrm{B}}$ - blank exceeds $5 \%$ of sample concentration

$\mathrm{U}_{\mathrm{E}}$ - value less than $10 \mathrm{x}$ the $\mathrm{DL}$

$\mathrm{U}_{\mathrm{R}}$ - fails $\% \mathrm{RSD}$ criteria $\mathrm{U}_{\mathrm{L}}$ - fails \% Recovery of LCS

ND - not detected
$\mathrm{U}_{\mathrm{M}}$ - fails minimum MRQ criteria $\mathrm{U}_{\mathrm{S}}$ - fails \% Recovery of MS

N/A - not applicable 
WSRC-TR-2003-00379, REV. 0

SRT-RPP-2003-00181, REV. 0

Table 5-5. Composition of the Aged 7 M Diluted 241-AW-101 Sample

\begin{tabular}{|c|c|c|c|c|c|c|c|c|c|}
\hline Analyte & $\begin{array}{c}\text { 1st } \\
\text { Replicate } \\
\text { (mg/L) }\end{array}$ & $\begin{array}{c}\text { 2nd } \\
\text { Replicate } \\
\text { (mg/L) }\end{array}$ & $\begin{array}{c}\text { 3rd } \\
\text { Replicate } \\
(\mathrm{mg} / \mathrm{L})\end{array}$ & $\begin{array}{c}\text { Average } \\
\text { (mg/L) }\end{array}$ & $\%$ RSD & $\begin{array}{c}\text { Blank } \\
(\mathrm{mg} / \mathrm{L})\end{array}$ & $\begin{array}{c}\text { LCS \% } \\
\text { Recovery }\end{array}$ & $\begin{array}{c}\text { MS \% } \\
\text { Recovery }\end{array}$ & $\begin{array}{c}\text { QC } \\
\text { Flag }\end{array}$ \\
\hline $\mathrm{NO}_{3}^{-}$(IC) & $1.23 \mathrm{E}+05$ & $1.23 \mathrm{E}+05$ & $1.21 \mathrm{E}+05$ & $1.22 \mathrm{E}+05$ & $1.2 \%$ & $<1.5 \mathrm{E}+02$ & $96 \%$ & $100 \%$ & \\
\hline $\mathrm{NO}_{2}^{-}$(IC) & $6.93 \mathrm{E}+04$ & $6.90 \mathrm{E}+04$ & $6.85 \mathrm{E}+04$ & $6.89 \mathrm{E}+04$ & $0.6 \%$ & $<1.5 \mathrm{E}+02$ & $104 \%$ & $140 \%$ & $\mathrm{U}_{\mathrm{S}}$ \\
\hline $\mathrm{PO}_{4}{ }^{3-}(\mathrm{IC})$ & $2.59 \mathrm{E}+02$ & $2.54 \mathrm{E}+02$ & $3.04 \mathrm{E}+02$ & $2.73 E+02$ & $10 \%$ & $<1.5 \mathrm{E}+02$ & $95 \%$ & $104 \%$ & $\mathrm{U}_{\mathrm{E}}$ \\
\hline $\mathrm{SO}_{4}{ }^{2-}$ (IC) & $2.11 \mathrm{E}+02$ & $2.07 \mathrm{E}+02$ & $2.08 \mathrm{E}+02$ & $2.08 \mathrm{E}+02$ & $1.0 \%$ & $<7.6 \mathrm{E}+01$ & $96 \%$ & $102 \%$ & $\mathrm{U}_{\mathrm{E}}$ \\
\hline $\mathrm{C}_{2} \mathrm{O}_{4}{ }^{2-}(\mathrm{IC})$ & $1.62 \mathrm{E}+02$ & $1.59 \mathrm{E}+02$ & $1.60 \mathrm{E}+02$ & $1.60 \mathrm{E}+02$ & $1.0 \%$ & $<1.5 \mathrm{E}+02$ & $98 \%$ & $104 \%$ & $\mathrm{U}_{\mathrm{E}}$ \\
\hline $\mathrm{Cl}^{-}$(IC) & $3.79 \mathrm{E}+03$ & $3.78 \mathrm{E}+03$ & $3.82 \mathrm{E}+03$ & $3.80 \mathrm{E}+03$ & $0.6 \%$ & $<3.0 \mathrm{E}+01$ & $98 \%$ & $104 \%$ & - \\
\hline $\mathrm{F}^{-}$(IC) & $4.37 \mathrm{E}+02$ & $4.61 \mathrm{E}+02$ & $4.48 \mathrm{E}+02$ & $4.49 \mathrm{E}+02$ & $2.6 \%$ & $<3.0 \mathrm{E}+01$ & $102 \%$ & $96 \%$ & - \\
\hline $\mathrm{CHO}_{2}^{-}$(IC) & $1.52 \mathrm{E}+03$ & $1.96 \mathrm{E}+03$ & $2.03 \mathrm{E}+03$ & $1.84 \mathrm{E}+03$ & $15 \%$ & $<1.5 \mathrm{E}+02$ & $97 \%$ & $98 \%$ & - \\
\hline $\mathrm{NH}_{4}^{+}(\mathrm{PT})$ & $6.48 \mathrm{E}+01$ & $7.95 \mathrm{E}+01$ & $9.60 \mathrm{E}+01$ & $8.01 \mathrm{E}+01$ & $19 \%$ & $7.59 \mathrm{E}+01$ & $105 \%$ & $114 \%$ & $\mathrm{U}_{\mathrm{R}}$ \\
\hline $\mathrm{OH}_{\text {free }}^{-}(\mathrm{T})$ & $5.29 \mathrm{E}+04$ & $5.30 \mathrm{E}+04$ & $4.68 \mathrm{E}+04$ & $5.09 \mathrm{E}+04$ & $7 \%$ & $<5.2 \mathrm{E}+02$ & $104 \%$ & N/A & - \\
\hline $\mathrm{OH}_{\text {total }}^{-}(\mathrm{T})$ & $7.27 \mathrm{E}+04$ & 7.14E +04 & $6.56 \mathrm{E}+04$ & $6.99 \mathrm{E}+04$ & $5 \%$ & $<5.2 \mathrm{E}+02$ & $101 \%$ & N/A & - \\
\hline TIC (A) & $1.20 \mathrm{E}+03$ & $1.14 \mathrm{E}+03$ & $1.04 \mathrm{E}+03$ & $1.13 \mathrm{E}+03$ & $7 \%$ & $<1.5 \mathrm{E}+01$ & $101 \%$ & $94 \%$ & - \\
\hline TOC (Diff) & $2.11 \mathrm{E}+03$ & $1.94 \mathrm{E}+03$ & $1.82 \mathrm{E}+03$ & $1.96 \mathrm{E}+03$ & $7 \%$ & $2.00 \mathrm{E}+01$ & $104 \%$ & $97 \%$ & - \\
\hline $\mathrm{Al}$ (IE) & $1.97 \mathrm{E}+04$ & $1.97 \mathrm{E}+04$ & $1.99 \mathrm{E}+04$ & $1.98 \mathrm{E}+04$ & $1 \%$ & $<1.7 \mathrm{E}+02$ & $101 \%$ & N/A & - \\
\hline B (IE) & $<9.0 \mathrm{E}+01$ & $<9.0 \mathrm{E}+01$ & $<8.7 \mathrm{E}+01$ & $<8.9 \mathrm{E}+01$ & - & $<8.6 \mathrm{E}+01$ & $100 \%$ & N/A & $\mathrm{U}_{\mathrm{M}}$ \\
\hline $\mathrm{Ba}$ (IE) & $<6.1 \mathrm{E}+01$ & $<6.1 \mathrm{E}+01$ & $<5.9 \mathrm{E}+01$ & $<6.0 \mathrm{E}+01$ & - & $<5.8 \mathrm{E}+01$ & $100 \%$ & $94 \%$ & $\mathrm{U}_{\mathrm{M}}$ \\
\hline $\mathrm{Ca}$ (IE) & $<7.4 \mathrm{E}+01$ & $<7.4 \mathrm{E}+01$ & $<7.1 \mathrm{E}+01$ & $<7.3 \mathrm{E}+01$ & - & $<7.0 \mathrm{E}+01$ & 96 & N/A & - \\
\hline Cd (IE) & $<1.4 \mathrm{E}+01$ & $<1.3 \mathrm{E}+01$ & $<1.3 \mathrm{E}+01$ & $<1.3 \mathrm{E}+01$ & - & $<1.3 \mathrm{E}+01$ & $100 \%$ & $93 \%$ & $\mathrm{U}_{\mathrm{M}}$ \\
\hline $\mathrm{Cr}$ (IE) & $3.01 \mathrm{E}+01$ & $2.93 \mathrm{E}+01$ & $3.63 \mathrm{E}+01$ & $3.19 \mathrm{E}+01$ & $12 \%$ & $<1.8 \mathrm{E}+01$ & $100 \%$ & $92 \%$ & $\mathrm{U}_{\mathrm{E}}$ \\
\hline $\mathrm{Fe}$ (IE) & $<1.2 \mathrm{E}+01$ & $<1.2 \mathrm{E}+01$ & $<1.1 \mathrm{E}+01$ & $<1.1 \mathrm{E}+01$ & - & $<1.1 \mathrm{E}+01$ & $99 \%$ & $93 \%$ & - \\
\hline $\mathrm{La}$ (IE) & $<2.3 \mathrm{E}+01$ & $<2.3 \mathrm{E}+01$ & $<2.2 \mathrm{E}+01$ & $<2.3 \mathrm{E}+01$ & - & $<2.2 \mathrm{E}+01$ & $102 \%$ & N/A & - \\
\hline $\mathrm{Li}$ (IE) & $<1.4 \mathrm{E}+02$ & $<1.4 \mathrm{E}+02$ & $<1.3 \mathrm{E}+02$ & $<1.4 \mathrm{E}+02$ & - & $<1.3 \mathrm{E}+02$ & $94 \%$ & N/A & $\mathrm{U}_{\mathrm{M}}$ \\
\hline $\mathrm{Mg}$ (IE) & $<1.7 \mathrm{E}+01$ & $<1.7 \mathrm{E}+01$ & $<1.6 \mathrm{E}+01$ & $<1.7 \mathrm{E}+01$ & - & $<1.6 \mathrm{E}+01$ & $102 \%$ & N/A & - \\
\hline $\mathrm{Na}$ (IE) & $1.66 \mathrm{E}+05$ & $1.65 \mathrm{E}+05$ & $1.60 \mathrm{E}+05$ & $1.64 \mathrm{E}+05$ & $2 \%$ & $<6.7 \mathrm{E}+01$ & $101 \%$ & $92 \%$ & - \\
\hline $\mathrm{Ni}$ (IE) & $<4.4 \mathrm{E}+01$ & $<4.3 \mathrm{E}+01$ & $<4.2 \mathrm{E}+01$ & $<4.3 \mathrm{E}+01$ & - & $<4.1 \mathrm{E}+01$ & $101 \%$ & $92 \%$ & $\mathrm{U}_{\mathrm{M}}$ \\
\hline $\mathrm{P}$ (IE) & $<2.2 \mathrm{E}+02$ & $<2.2 \mathrm{E}+02$ & $<2.2 \mathrm{E}+02$ & $<2.2 \mathrm{E}+02$ & - & $<2.1 \mathrm{E}+02$ & $97 \%$ & N/A & - \\
\hline
\end{tabular}

* Single value

** Average of two replicates

QC Flags: none - meets all QC

$\mathrm{U}_{\mathrm{B}}$ - blank exceeds $5 \%$ of sample concentration

$\mathrm{U}_{\mathrm{R}}$ - fails \%RSD criteria

$\mathrm{U}_{\mathrm{M}}$ - fails minimum MRQ criteria

$\mathrm{U}_{\mathrm{E}}-$ value less than $10 \mathrm{x}$ the $\mathrm{DL}$

$\mathrm{U}_{\mathrm{L}}$ - fails \% Recovery of LCS

ND - not detected
$\mathrm{U}_{\mathrm{S}}$ - fails \% Recovery of MS

N/A - not applicable 
WSRC-TR-2003-00379, REV. 0

SRT-RPP-2003-00181, REV. 0

Table 5-5. Composition of the Aged 7 M Diluted 241-AW-101 Sample - continued

\begin{tabular}{|c|c|c|c|c|c|c|c|c|c|}
\hline Analyte & $\begin{array}{c}\text { 1st } \\
\text { Replicate } \\
\text { (mg/L) }\end{array}$ & $\begin{array}{c}\text { 2nd } \\
\text { Replicate } \\
(\mathrm{mg} / \mathrm{L}) \\
\end{array}$ & $\begin{array}{c}\text { 3rd } \\
\text { Replicate } \\
(\mathrm{mg} / \mathrm{L})\end{array}$ & $\begin{array}{c}\text { Average } \\
\text { (mg/L) }\end{array}$ & $\%$ RSD & $\begin{array}{c}\text { Blank } \\
(\mathrm{mg} / \mathrm{L})\end{array}$ & \begin{tabular}{|} 
LCS \% \\
Recovery
\end{tabular} & $\begin{array}{c}\text { MS \% } \\
\text { Recovery }\end{array}$ & $\begin{array}{c}\text { QC } \\
\text { Flag }\end{array}$ \\
\hline $\mathrm{Pb}$ (IE) & $<1.0 \mathrm{E}+02$ & $<1.0 \mathrm{E}+02$ & $<9.9 \mathrm{E}+01$ & $<1.0 \mathrm{E}+02$ & - & $<9.8 \mathrm{E}+01$ & $100 \%$ & N/A & - \\
\hline $\mathrm{U}(\mathrm{IE})$ & $<7.3 \mathrm{E}+02$ & $<7.3 \mathrm{E}+02$ & $<7.0 \mathrm{E}+02$ & $<7.2 \mathrm{E}+02$ & - & $<7.0 \mathrm{E}+02$ & $100 \%$ & N/A & - \\
\hline $\mathrm{K}(\mathrm{IE})$ & $2.74 \mathrm{E}+04$ & $2.72 \mathrm{E}+04$ & $2.90 \mathrm{E}+04$ & $2.79 \mathrm{E}+04$ & $4 \%$ & $<2.9 \mathrm{E}+03$ & $95 \%$ & N/A & - \\
\hline $\mathrm{S} \quad$ (IE) & $<4.4 \mathrm{E}+02$ & $<4.4 \mathrm{E}+02$ & $<4.3 \mathrm{E}+02$ & $<4.3 \mathrm{E}+02$ & - & $<4.2 \mathrm{E}+02$ & $94 \%$ & N/A & $\mathrm{U}_{\mathrm{M}}$ \\
\hline $\mathrm{Ce}$ (IE) & $9.68 \mathrm{E}+01$ & $<8.6 \mathrm{E}+01$ & $<8.4 \mathrm{E}+01$ & $9.68 \mathrm{E}+01^{*}$ & - & $<8.3 \mathrm{E}+01$ & $104 \%$ & N/A & $\mathrm{U}_{\mathrm{E}}$ \\
\hline $\mathrm{V}$ (IE) & $<6.4 \mathrm{E}+00$ & $<6.4 \mathrm{E}+00$ & $<6.2 \mathrm{E}+00$ & $<6.3 \mathrm{E}+00$ & - & $<6.1 \mathrm{E}+00$ & $102 \%$ & N/A & $\mathrm{U}_{\mathrm{M}}$ \\
\hline $\mathrm{Na}(\mathrm{AA})$ & $1.65 \mathrm{E}+05$ & $1.62 \mathrm{E}+05$ & $1.62 \mathrm{E}+05$ & $1.63 \mathrm{E}+05$ & $1 \%$ & $4.73 E+03$ & $101 \%$ & $98 \%$ & - \\
\hline $\mathrm{K}(\mathrm{AA})$ & $2.88 \mathrm{E}+04$ & $2.84 \mathrm{E}+04$ & $2.87 \mathrm{E}+04$ & $2.86 \mathrm{E}+04$ & $1 \%$ & $<6.9 \mathrm{E}+02$ & $103 \%$ & $101 \%$ & - \\
\hline $\mathrm{Hg}(\mathrm{AA})$ & $<1.8 \mathrm{E}+00$ & $<1.8 \mathrm{E}+00$ & $<1.7 \mathrm{E}+00$ & $<1.7 \mathrm{E}+00$ & - & $<1.7 \mathrm{E}+00$ & $90 \%$ & $90 \%$ & $\mathrm{U}_{\mathrm{M}}$ \\
\hline Citrate (IC) & $<1.6 \mathrm{E}+02$ & $<1.6 \mathrm{E}+02$ & $<1.6 \mathrm{E}+02$ & $<1.6 \mathrm{E}+02$ & - & $<1.5 \mathrm{E}+02$ & $108 \%$ & $19 \%$ & $\mathrm{U}_{\mathrm{S}}$ \\
\hline Glycolate (IC) & $3.24 \mathrm{E}+02$ & $2.86 \mathrm{E}+02$ & $2.88 \mathrm{E}+02$ & $2.99 \mathrm{E}+02$ & $7 \%$ & $<1.5 \mathrm{E}+02$ & $100 \%$ & $89 \%$ & $\mathrm{U}_{\mathrm{E}}$ \\
\hline Acetate (IC) & $9.88 \mathrm{E}+02$ & $9.54 \mathrm{E}+02$ & $8.96 \mathrm{E}+02$ & $9.46 \mathrm{E}+02$ & $5 \%$ & $<1.5 \mathrm{E}+02$ & $100 \%$ & $76 \%$ & $\mathrm{U}_{\mathrm{E}}$ \\
\hline EDTA (HL) & $<8.1 \mathrm{E}+02$ & $<8.0 \mathrm{E}+02$ & $<8.0 \mathrm{E}+02$ & $<8.0 \mathrm{E}+02$ & - & $<7.6 \mathrm{E}+02$ & $100 \%$ & $100 \%$ & - \\
\hline $\operatorname{HEDTA}(\mathrm{HL})$ & $<8.1 \mathrm{E}+02$ & $<8.0 \mathrm{E}+02$ & $<8.0 \mathrm{E}+02$ & $<8.0 \mathrm{E}+02$ & - & $<7.6 \mathrm{E}+02$ & $98 \%$ & $97 \%$ & - \\
\hline IDA (GM) & $<1.6 \mathrm{E}+03$ & $<1.6 \mathrm{E}+03$ & $<1.6 \mathrm{E}+03$ & $<1.6 \mathrm{E}+03$ & - & $<1.5 \mathrm{E}+03$ & $96 \%$ & $86 \%$ & - \\
\hline NTA (GM) & $<1.6 \mathrm{E}+03$ & $<1.6 \mathrm{E}+03$ & $<1.6 \mathrm{E}+03$ & $<1.6 \mathrm{E}+03$ & - & $<1.5 \mathrm{E}+03$ & $96 \%$ & $86 \%$ & - \\
\hline ED3A (GM) & ND & ND & ND & - & - & ND & - & - & - \\
\hline $\mathrm{Rb}$ (IM) & $8.66 \mathrm{E}+00$ & $8.78 \mathrm{E}+00$ & $8.35 \mathrm{E}+00$ & $8.60 \mathrm{E}+00$ & $3 \%$ & $5.93 \mathrm{E}-03$ & $133 \%$ & $101 \%$ & $\mathrm{U}_{\mathrm{L}}$ \\
\hline W (IM) & $7.38 \mathrm{E}+01$ & $7.54 \mathrm{E}+01$ & $7.05 \mathrm{E}+01$ & $7.32 \mathrm{E}+01$ & $3 \%$ & $2.00 \mathrm{E}-03$ & - & $100 \%$ & - \\
\hline Th (IM) & $<5.1 \mathrm{E}-03$ & $<5.1 \mathrm{E}-03$ & $<4.9 \mathrm{E}-03$ & $<5.1 \mathrm{E}-03$ & - & $<9.7 \mathrm{E}-04$ & $90 \%$ & $90 \%$ & - \\
\hline $\mathrm{I}^{127}$ (IM) & $1.29 \mathrm{E}+01$ & $1.29 \mathrm{E}+01$ & $1.25 \mathrm{E}+01$ & $1.28 \mathrm{E}+01$ & $2 \%$ & $1.27 \mathrm{E}-01$ & $89 \%$ & - & - \\
\hline $\mathrm{Cs}^{133}$ (IM) & $7.89 \mathrm{E}+00$ & $7.94 \mathrm{E}+00$ & $7.50 \mathrm{E}+00$ & $7.78 \mathrm{E}+00$ & $3 \%$ & $4.23 \mathrm{E}-02$ & $121 \%$ & - & $\mathrm{U}_{\mathrm{L}}$ \\
\hline $\mathrm{Cs}^{135}$ (IM) & $1.85 \mathrm{E}+00$ & $1.85 \mathrm{E}+00$ & $1.75 \mathrm{E}+00$ & $1.82 \mathrm{E}+00$ & $3 \%$ & $1.09 \mathrm{E}-03$ & - & $89 \%$ & - \\
\hline $\mathrm{Cs}^{137}$ (IM) & $2.62 \mathrm{E}+00$ & $2.69 \mathrm{E}+00$ & $2.56 \mathrm{E}+00$ & $2.62 \mathrm{E}+00$ & $2 \%$ & $1.81 \mathrm{E}-03$ & $119 \%$ & $89 \%$ & - \\
\hline
\end{tabular}

* Single value

** Average of two replicates

QC Flags: none - meets all QC

$\mathrm{U}_{\mathrm{B}}$ - blank exceeds $5 \%$ of sample concentration

$\mathrm{U}_{\mathrm{E}}$ - value less than $10 \mathrm{x}$ the $\mathrm{DL}$

$\mathrm{U}_{\mathrm{R}}$ - fails \%RSD criteria

$\mathrm{U}_{\mathrm{L}}$ - fails \% Recovery of LCS

ND - not detected
$\mathrm{U}_{\mathrm{M}}$ - fails minimum MRQ criteria

$\mathrm{U}_{\mathrm{S}}$ - fails \% Recovery of MS

N/A - not applicable 
WSRC-TR-2003-00379, REV. 0

SRT-RPP-2003-00181, REV. 0

Table 5-5. Composition of the Aged 7 M Diluted 241-AW-101 Sample - continued

\begin{tabular}{|c|c|c|c|c|c|c|c|c|c|}
\hline Analyte & $\begin{array}{c}\text { 1st } \\
\text { Replicate } \\
\text { (mCi/L) }\end{array}$ & $\begin{array}{c}\text { 2nd } \\
\text { Replicate } \\
\text { (mCi/L) }\end{array}$ & $\begin{array}{c}\text { 3rd } \\
\text { Replicate } \\
(\mathrm{mCi} / \mathrm{L})\end{array}$ & $\begin{array}{l}\text { Average } \\
(\mathbf{m C i} / \mathbf{L})\end{array}$ & $\%$ RSD & $\begin{array}{c}\text { Blank } \\
(\mathbf{m C i} / \mathbf{L})\end{array}$ & \begin{tabular}{|c|} 
LCS \% \\
Recovery
\end{tabular} & $\begin{array}{c}\text { MS \% } \\
\text { Recovery }\end{array}$ & $\begin{array}{c}\text { QC } \\
\text { Flag }\end{array}$ \\
\hline $\mathrm{Cs}^{137}(\mathrm{GS})$ & $3.05 \mathrm{E}+02$ & $2.68 \mathrm{E}+02$ & $3.03 \mathrm{E}+02$ & $2.92 \mathrm{E}+02$ & $7 \%$ & $<2.6 \mathrm{E}-02$ & N/A & N/A & - \\
\hline $\mathrm{Eu}^{154}(\mathrm{GS})$ & $<7.8 \mathrm{E}-05$ & $<6.1 \mathrm{E}-05$ & $<4.6 \mathrm{E}-05$ & $<6.2 \mathrm{E}-05$ & - & $<2.6 \mathrm{E}-05$ & N/A & N/A & - \\
\hline $\mathrm{Eu}^{155}(\mathrm{GS})$ & $<1.5 \mathrm{E}-04$ & $<4.7 \mathrm{E}-04$ & $<7.1 \mathrm{E}-05$ & $<2.3 \mathrm{E}-04$ & - & $<3.4 \mathrm{E}-05$ & N/A & N/A & - \\
\hline $\mathrm{Co}^{60}(\mathrm{GS})$ & $3.70 \mathrm{E}-04$ & $3.84 \mathrm{E}-04$ & $3.63 \mathrm{E}-04$ & 3.72E-04 & $3 \%$ & $<2.2 \mathrm{E}-05$ & N/A & N/A & - \\
\hline $\mathrm{Sn}^{126}(\mathrm{GS})$ & $<6.5 \mathrm{E}-04$ & $<4.2 \mathrm{E}-04$ & $<4.1 \mathrm{E}-04$ & $<4.9 \mathrm{E}-04$ & - & $<2.8 \mathrm{E}-05$ & N/A & N/A & - \\
\hline $\mathrm{Pa}^{231}(\mathrm{GS})$ & $<4.0 \mathrm{E}-03$ & $<4.1 \mathrm{E}-03$ & $<1.2 \mathrm{E}-03$ & $<3.1 \mathrm{E}-03$ & - & $<5.7 \mathrm{E}-04$ & N/A & N/A & $\mathrm{U}_{\mathrm{M}}$ \\
\hline $\mathrm{Sr}^{90}(\mathrm{SL})$ & $4.55 \mathrm{E}-02$ & $4.27 \mathrm{E}-02$ & $4.87 \mathrm{E}-02$ & $4.56 \mathrm{E}-02$ & $6 \%$ & $<6.4 \mathrm{E}-03$ & $101 \%$ & $96 \%$ & - \\
\hline $\mathrm{Se}^{79}$ (SL) & $2.60 \mathrm{E}-04$ & $<4.3 \mathrm{E}-04$ & $<3.5 \mathrm{E}-04$ & $2.60 \mathrm{E}-04^{*}$ & - & $<1.3 \mathrm{E}-04$ & N/A & N/A & $\mathrm{U}_{\mathrm{E}}$ \\
\hline $\mathrm{H}^{3}(\mathrm{SL})$ & $2.58 \mathrm{E}-03$ & $2.56 \mathrm{E}-03$ & $2.32 \mathrm{E}-03$ & $2.49 \mathrm{E}-03$ & $6 \%$ & $5.00 \mathrm{E}-05$ & $83 \%$ & $91 \%$ & - \\
\hline $\mathrm{C}^{14}(\mathrm{SL})$ & $<6.1 \mathrm{E}-04$ & $<5.8 \mathrm{E}-04$ & $<6.2 \mathrm{E}-04$ & $<6.1 \mathrm{E}-04$ & - & $<4.6 \mathrm{E}-05$ & $105 \%$ & $104 \%$ & - \\
\hline $\mathrm{Tc}^{99}{ }_{\text {pertech }}(\mathrm{SL})$ & $1.07 \mathrm{E}-01$ & $1.05 \mathrm{E}-01$ & $9.95 \mathrm{E}-02$ & $1.04 \mathrm{E}-01$ & $4 \%$ & $<8.1 \mathrm{E}-05$ & N/A & N/A & - \\
\hline $\mathrm{I}^{129}(\mathrm{SG})$ & $1.47 \mathrm{E}-04$ & $1.49 \mathrm{E}-04$ & $1.50 \mathrm{E}-04$ & 1.49E-04 & $1 \%$ & $<1.8 \mathrm{E}-06$ & N/A & N/A & - \\
\hline $\mathrm{Pu}^{238}(\mathrm{SA})$ & $6.37 \mathrm{E}-04$ & $5.68 \mathrm{E}-04$ & $6.73 \mathrm{E}-04$ & $6.26 \mathrm{E}-04$ & $9 \%$ & $<1.0 \mathrm{E}-05$ & N/A & N/A & - \\
\hline $\mathrm{Pu}^{239 / 240}(\mathrm{SA})$ & $1.04 \mathrm{E}-04$ & $1.02 \mathrm{E}-04$ & $1.39 \mathrm{E}-04$ & $1.15 \mathrm{E}-04$ & $18 \%$ & $<1.3 \mathrm{E}-05$ & N/A & N/A & $\mathrm{U}_{\mathrm{R}}$ \\
\hline $\mathrm{Pu}^{241}(\mathrm{SA})$ & $8.05 \mathrm{E}-04$ & $6.68 \mathrm{E}-04$ & $1.01 \mathrm{E}-03$ & $8.28 \mathrm{E}-04$ & $21 \%$ & $<2.8 \mathrm{E}-04$ & N/A & N/A & $\mathrm{U}_{\mathrm{R}}$ \\
\hline $\mathrm{Am}^{241}(\mathrm{SG})$ & $<7.7 \mathrm{E}-02$ & $<3.0 \mathrm{E}-03$ & $<1.5 \mathrm{E}-03$ & $<2.7 \mathrm{E}-02$ & - & $<2.3 \mathrm{E}-03$ & N/A & N/A & - \\
\hline $\mathrm{Cm}^{242}(\mathrm{SA})$ & $<3.4 \mathrm{E}-04$ & $<2.8 \mathrm{E}-05$ & $<2.8 \mathrm{E}-05$ & $<1.3 \mathrm{E}-04$ & - & $<6.4 \mathrm{E}-05$ & N/A & N/A & - \\
\hline $\mathrm{Cm}^{243 / 244}(\mathrm{SA})$ & $<3.0 \mathrm{E}-03$ & $<2.4 \mathrm{E}-04$ & $<8.8 \mathrm{E}-04$ & $<1.4 \mathrm{E}-03$ & - & $<3.2 \mathrm{E}-04$ & N/A & N/A & - \\
\hline $\mathrm{Tc}^{99}$ total (IM) & $1.11 \mathrm{E}-01$ & $1.14 \mathrm{E}-01$ & $1.08 \mathrm{E}-01$ & -01 & $3 \%$ & E-05 & - & - & - \\
\hline $\mathrm{Np}^{237}$ (IM) & $<3.6 \mathrm{E}-06$ & $<3.6 \mathrm{E}-06$ & $<3.5 \mathrm{E}-06$ & $<3.6 \mathrm{E}-06$ & - & $<6.9 \mathrm{E}-07$ & - & - & - \\
\hline $\mathrm{Pu}^{239}(\mathrm{IM})$ & $<3.2 \mathrm{E}-04$ & $<3.1 \mathrm{E}-04$ & $<3.0 \mathrm{E}-04$ & $<3.1 \mathrm{E}-04$ & - & $9.22 \mathrm{E}-05$ & - & - & - \\
\hline $\mathrm{Pu}^{240}$ (IM) & $<1.2 \mathrm{E}-03$ & $<1.2 \mathrm{E}-03$ & $<1.1 \mathrm{E}-03$ & $<1.1 \mathrm{E}-03$ & - & $<2.2 \mathrm{E}-04$ & - & - & - \\
\hline $\mathrm{U}^{233}$ (IM) & $<5.0 \mathrm{E}-05$ & $<4.9 \mathrm{E}-05$ & $<4.8 \mathrm{E}-05$ & $<4.9 \mathrm{E}-05$ & - & $<9.4 \mathrm{E}-06$ & - & - & - \\
\hline $\mathrm{U}^{234}$ (IM) & $<3.2 \mathrm{E}-05$ & $<3.2 \mathrm{E}-05$ & $<3.1 \mathrm{E}-05$ & $<3.2 \mathrm{E}-05$ & - & $<6.1 \mathrm{E}-06$ & - & - & - \\
\hline
\end{tabular}

* Single value

** Average of two replicates

QC Flags: none - meets all QC

$\mathrm{U}_{\mathrm{B}}$ - blank exceeds $5 \%$ of sample concentration

$\mathrm{U}_{\mathrm{E}}$ - value less than $10 \mathrm{x}$ the $\mathrm{DL}$

$\mathrm{U}_{\mathrm{R}}$ - fails $\% \mathrm{RSD}$ criteria

$\mathrm{U}_{\mathrm{L}}$ - fails \% Recovery of LCS

ND - not detected
$\mathrm{U}_{\mathrm{M}}$ - fails minimum MRQ criteria

$\mathrm{U}_{\mathrm{S}}$ - fails \% Recovery of MS

N/A - not applicable 
WSRC-TR-2003-00379, REV. 0

SRT-RPP-2003-00181, REV. 0

Table 5-5. Composition of the Aged 7 M Diluted 241-AW-101 Sample - continued

\begin{tabular}{|l|c|c|c|c|c|c|c|c|c|}
\hline \multicolumn{1}{|c|}{ Analyte } & $\begin{array}{c}\mathbf{1 s t} \\
\text { Replicate } \\
(\mathbf{m C i} / \mathbf{L})\end{array}$ & $\begin{array}{c}\mathbf{2 n d} \\
\text { Replicate } \\
(\mathbf{m C i} / \mathbf{L})\end{array}$ & $\begin{array}{c}\text { 3rd } \\
\text { Replicate } \\
(\mathbf{m C i} / \mathbf{L})\end{array}$ & $\begin{array}{c}\text { Average } \\
(\mathbf{m C i} / \mathbf{L})\end{array}$ & $\mathbf{\% R S D}$ & $\begin{array}{c}\text { Blank } \\
(\mathbf{m C i} / \mathbf{L})\end{array}$ & $\begin{array}{c}\text { LCS \% } \\
\text { Recovery }\end{array}$ & $\begin{array}{c}\text { MS \% } \\
\text { Recovery }\end{array}$ & $\begin{array}{c}\text { QC } \\
\text { Flag }\end{array}$ \\
\hline $\mathrm{U}^{235}(\mathrm{IM})$ & $3.11 \mathrm{E}-08$ & $3.32 \mathrm{E}-08$ & $2.85 \mathrm{E}-08$ & $3.09 \mathrm{E}-08$ & $8 \%$ & $<2.1 \mathrm{E}-09$ & $81 \%$ & $90 \%$ & $\mathrm{U}_{\mathrm{E}}$ \\
\hline $\mathrm{U}^{236}(\mathrm{IM})$ & $<3.3 \mathrm{E}-07$ & $<3.3 \mathrm{E}-07$ & $<3.2 \mathrm{E}-07$ & $<3.3 \mathrm{E}-07$ & - & $6.46 \mathrm{E}-08$ & - & - & - \\
\hline $\mathrm{U}^{238}(\mathrm{IM})$ & $5.64 \mathrm{E}-07$ & $5.75 \mathrm{E}-07$ & $5.34 \mathrm{E}-07$ & $5.58 \mathrm{E}-07$ & $4 \%$ & $7.48 \mathrm{E}-08$ & $96 \%$ & $88 \%$ & $\mathrm{U}_{\mathrm{B}}$ \\
\hline Alpha (AC) & $4.99 \mathrm{E}-03$ & $7.06 \mathrm{E}-03$ & $3.89 \mathrm{E}-03$ & $5.31 \mathrm{E}-03$ & $30 \%$ & $<3.3 \mathrm{E}-03$ & $83 \%$ & $83 \%$ & $\mathrm{U}_{\mathrm{E}} \mathrm{U}_{\mathrm{R}}$ \\
\hline Alpha $_{\text {sum }}$ & - & - & - & $<2.9 \mathrm{E}-02$ & - & $<2.3 \mathrm{E}-03$ & N/A & N/A & - \\
\hline
\end{tabular}

* Single value

** Average of two replicates

QC Flags: none - meets all QC

$\mathrm{U}_{\mathrm{B}}$ - blank exceeds $5 \%$ of sample concentration

$\mathrm{U}_{\mathrm{E}}$ - value less than $10 \mathrm{x}$ the $\mathrm{DL}$

$\mathrm{U}_{\mathrm{R}}$ - fails $\% \mathrm{RSD}$ criteria $\mathrm{U}_{\mathrm{L}}$ - fails \% Recovery of LCS

ND - not detected
$\mathrm{U}_{\mathrm{M}}$ - fails minimum MRQ criteria $\mathrm{U}_{\mathrm{S}}$ - fails \% Recovery of MS

N/A - not applicable 
WSRC-TR-2003-00379, REV. 0

SRT-RPP-2003-00181, REV. 0

Table 5-6. Comparison of Un-Aged and Aged 7 M Diluted 241-AW-101 Sample

\begin{tabular}{|c|c|c|c|c|c|}
\hline Analyte & $\begin{array}{c}\text { Un-Aged } \\
\text { Average } \\
\text { (mg/L) }\end{array}$ & $\begin{array}{l}\text { Un-Aged } \\
\text { QC Flag }\end{array}$ & $\begin{array}{c}\text { Aged } \\
\text { Average } \\
\text { (mg/L) } \\
\end{array}$ & $\begin{array}{c}\text { Aged } \\
\text { QC Flag }\end{array}$ & $\begin{array}{c}\text { Percent } \\
\text { Difference }\end{array}$ \\
\hline $\mathrm{NO}_{3}^{-}$(IC) & $1.06 \mathrm{E}+05$ & - & $1.22 \mathrm{E}+05$ & - & $15 \%$ \\
\hline $\mathrm{NO}_{2}^{-}$(IC) & $6.36 \mathrm{E}+04$ & - & $6.89 \mathrm{E}+04$ & $\mathrm{U}_{\mathrm{S}}$ & $8 \%$ \\
\hline $\mathrm{PO}_{4}{ }^{3-}{ }^{(\mathrm{IC})}$ & $2.92 \mathrm{E}+02$ & $\mathrm{U}_{\mathrm{E}}$ & $2.73 \mathrm{E}+02$ & $\mathrm{U}_{\mathrm{E}}$ & $-7 \%$ \\
\hline $\mathrm{SO}_{4}^{2-}$ (IC) & $1.92 \mathrm{E}+02$ & $\mathrm{U}_{\mathrm{E}}$ & $2.08 \mathrm{E}+02$ & $\mathrm{U}_{\mathrm{E}}$ & $8 \%$ \\
\hline $\mathrm{C}_{2} \mathrm{O}_{4}{ }^{2-}(\mathrm{IC})$ & $1.79 \mathrm{E}+02$ & $\mathrm{U}_{\mathrm{E}}$ & $1.60 \mathrm{E}+02$ & $\mathrm{U}_{\mathrm{E}}$ & $-10 \%$ \\
\hline $\mathrm{Cl}^{-}$(IC) & $3.55 \mathrm{E}+03$ & - & $3.80 \mathrm{E}+03$ & - & $7 \%$ \\
\hline $\mathrm{F}^{-}(\mathrm{IC})$ & $3.11 \mathrm{E}+02$ & $\mathrm{U}_{\mathrm{E}}$ & $4.49 \mathrm{E}+02$ & - & $44 \%$ \\
\hline $\mathrm{CHO}_{2}^{-}$(IC) & $1.64 \mathrm{E}+03$ & $\mathrm{U}_{\mathrm{E}}$ & $1.84 \mathrm{E}+03$ & - & $12 \%$ \\
\hline $\mathrm{NH}_{4}^{+}(\mathrm{PT})$ & $<9.9 \mathrm{E}+01$ & - & $8.01 \mathrm{E}+01$ & $\mathrm{U}_{\mathrm{R}}$ & - \\
\hline $\mathrm{OH}_{\text {free }}^{-}(\mathrm{T})$ & $4.14 \mathrm{E}+04$ & - & $5.09 \mathrm{E}+04$ & - & $23 \%$ \\
\hline $\mathrm{OH}_{\text {total }}^{-}(\mathrm{T})$ & $5.84 \mathrm{E}+04$ & - & $6.99 \mathrm{E}+04$ & - & $20 \%$ \\
\hline TIC (A) & $7.94 \mathrm{E}+02$ & - & $1.13 \mathrm{E}+03$ & - & $42 \%$ \\
\hline TOC (Diff) & $1.63 \mathrm{E}+03$ & - & $1.96 \mathrm{E}+03$ & - & $20 \%$ \\
\hline $\mathrm{Al}$ (IE) & $1.86 \mathrm{E}+04$ & - & $1.98 \mathrm{E}+04$ & - & $6 \%$ \\
\hline B (IE) & $2.17 \mathrm{E}+01$ & - & $<8.9 \mathrm{E}+01$ & $\mathrm{U}_{\mathrm{M}}$ & - \\
\hline $\mathrm{Ba}$ (IE) & $1.86 \mathrm{E}+00$ & - & $<6.0 \mathrm{E}+01$ & $\mathrm{U}_{\mathrm{M}}$ & - \\
\hline $\mathrm{Ca}(\mathrm{IE})$ & $<5.6 \mathrm{E}+00$ & $\mathrm{U}_{\mathrm{E}}$ & $<7.3 \mathrm{E}+01$ & - & - \\
\hline Cd (IE) & $1.86 \mathrm{E}+00$ & - & $<1.3 \mathrm{E}+01$ & $\mathrm{U}_{\mathrm{M}}$ & - \\
\hline $\mathrm{Cr}$ (IE) & $6.37 \mathrm{E}+01$ & - & $3.19 \mathrm{E}+01$ & $\mathrm{U}_{\mathrm{E}}$ & $-50 \%$ \\
\hline $\mathrm{Fe}$ (IE) & $2.82 \mathrm{E}+00$ & - & $<1.1 \mathrm{E}+01$ & - & - \\
\hline La (IE) & $2.32 \mathrm{E}+00$ & - & $<2.3 \mathrm{E}+01$ & - & - \\
\hline Li (IE) & $<1.1 \mathrm{E}+01$ & $\mathrm{U}_{\mathrm{M}}$ & $<1.4 \mathrm{E}+02$ & $\mathrm{U}_{\mathrm{M}}$ & - \\
\hline $\mathrm{Mg}$ (IE) & $<1.3 \mathrm{E}+00$ & - & $<1.7 \mathrm{E}+01$ & - & - \\
\hline $\mathrm{Na}$ (IE) & $1.70 \mathrm{E}+05$ & - & $1.64 \mathrm{E}+05$ & - & $-4 \%$ \\
\hline $\mathrm{Ni}$ (IE) & $3.71 \mathrm{E}+00$ & - & $<4.3 \mathrm{E}+01$ & $\mathrm{U}_{\mathrm{M}}$ & - \\
\hline $\mathrm{P}$ (IE) & $2.21 \mathrm{E}+02$ & - & $<2.2 \mathrm{E}+02$ & - & - \\
\hline
\end{tabular}

* Single value

** Average of two replicates

*** The percent difference was calculated by subtracting the Un-Aged value from the Aged value and dividing by the UnAged value.

QC Flags: none - meets all QC

$\mathrm{U}_{\mathrm{B}}$ - blank exceeds $5 \%$ of sample concentration

$\mathrm{U}_{\mathrm{E}}$ - value less than $10 \mathrm{x}$ the $\mathrm{DL}$

$\mathrm{U}_{\mathrm{R}}$ - fails \%RSD criteria $\mathrm{U}_{\mathrm{L}}$ - fails \% Recovery of LCS ND - not detected
$\mathrm{U}_{\mathrm{M}}$ - fails minimum MRQ criteria $\mathrm{U}_{\mathrm{S}}$ - fails \% Recovery of MS

N/A - not applicable 
WSRC-TR-2003-00379, REV. 0

SRT-RPP-2003-00181, REV. 0

Table 5-6. Comparison of Un-Aged and Aged 7 M Diluted 241-AW-101 Sample continued

\begin{tabular}{|c|c|c|c|c|c|}
\hline Analyte & $\begin{array}{c}\text { Un-Aged } \\
\text { Average } \\
\text { (mg/L) }\end{array}$ & $\begin{array}{l}\text { Un-Aged } \\
\text { QC Flag }\end{array}$ & $\begin{array}{c}\text { Aged } \\
\text { Average } \\
(\mathrm{mg} / \mathrm{L})\end{array}$ & $\begin{array}{c}\text { Aged } \\
\text { QC Flag }\end{array}$ & $\begin{array}{c}\text { Percent } \\
\text { Difference }\end{array}$ \\
\hline $\mathrm{Pb}$ (IE) & $2.92 \mathrm{E}+01$ & - & $<1.0 \mathrm{E}+02$ & - & - \\
\hline $\mathrm{U}(\mathrm{IE})$ & $<1.2 \mathrm{E}+02$ & $\mathrm{U}_{\mathrm{E}}$ & $<7.2 \mathrm{E}+02$ & - & - \\
\hline $\mathrm{K}$ (IE) & $3.13 \mathrm{E}+04$ & - & $2.79 \mathrm{E}+04$ & - & $-11 \%$ \\
\hline $\mathrm{S} \quad$ (IE) & $2.59 \mathrm{E}+02$ & - & $<4.3 \mathrm{E}+02$ & $\mathrm{U}_{\mathrm{M}}$ & - \\
\hline $\mathrm{Ce}$ (IE) & $<6.6 \mathrm{E}+00$ & $\mathrm{U}_{\mathrm{M}}$ & $9.68 \mathrm{E}-01 *$ & $\mathrm{U}_{\mathrm{E}}$ & - \\
\hline$V$ (IE) & $<4.9 \mathrm{E}-01$ & - & $<6.3 \mathrm{E}+00$ & $\mathrm{U}_{\mathrm{M}}$ & - \\
\hline $\mathrm{Na}(\mathrm{AA})$ & $1.54 \mathrm{E}+05$ & - & $1.63 \mathrm{E}+05$ & - & $6 \%$ \\
\hline $\mathrm{K}(\mathrm{AA})$ & $2.93 \mathrm{E}+04$ & - & $2.86 \mathrm{E}+04$ & - & $-2 \%$ \\
\hline $\mathrm{Hg}(\mathrm{AA})$ & $<2.2 \mathrm{E}+00$ & $\mathrm{U}_{\mathrm{M}}$ & $<1.7 \mathrm{E}+00$ & $\mathrm{U}_{\mathrm{M}}$ & - \\
\hline Citrate (IC) & $<2.0 \mathrm{E}+02$ & $\mathrm{U}_{\mathrm{M}} \mathrm{U}_{\mathrm{S}}$ & $<1.6 \mathrm{E}+02$ & $\mathrm{U}_{\mathrm{S}}$ & - \\
\hline Glycolate (IC) & $3.97 \mathrm{E}+02$ & - & $2.99 \mathrm{E}+02$ & $\mathrm{U}_{\mathrm{E}}$ & $-25 \%$ \\
\hline Acetate (IC) & $1.21 \mathrm{E}+03$ & - & $9.46 \mathrm{E}+02$ & $\mathrm{U}_{\mathrm{E}}$ & $-22 \%$ \\
\hline EDTA (HL) & $<2.0 \mathrm{E}+02$ & $\mathrm{U}_{\mathrm{M}}$ & $<8.0 \mathrm{E}+02$ & - & - \\
\hline HEDTA (HL) & $<2.0 \mathrm{E}+02$ & $\mathrm{U}_{\mathrm{M}}$ & $<8.0 \mathrm{E}+02$ & - & - \\
\hline IDA (GM) & $<9.9 \mathrm{E}+02$ & - & $<1.6 \mathrm{E}+03$ & - & - \\
\hline NTA (GM) & $<9.9 \mathrm{E}+02$ & - & $<1.6 \mathrm{E}+03$ & - & - \\
\hline ED3A (GM) & ND & - & ND & - & - \\
\hline $\mathrm{Rb}$ (IM) & $6.40 \mathrm{E}+00$ & - & $8.60 \mathrm{E}+00$ & $\mathrm{U}_{\mathrm{L}}$ & $34 \%$ \\
\hline W (IM) & $7.21 \mathrm{E}+01$ & $\mathrm{U}_{\mathrm{S}}$ & $7.32 \mathrm{E}+01$ & - & $1 \%$ \\
\hline Th (IM) & $2.74 \mathrm{E}-02$ & - & $<5.1 \mathrm{E}-03$ & - & - \\
\hline $\mathrm{I}^{127}$ (IM) & $1.13 \mathrm{E}+00$ & $\mathrm{U}_{\mathrm{B}}$ & $1.28 \mathrm{E}+01$ & - & $1027 \%$ \\
\hline $\mathrm{Cs}^{133}$ (IM) & $1.05 \mathrm{E}+01$ & - & $7.78 \mathrm{E}+00$ & $\mathrm{U}_{\mathrm{L}}$ & $-26 \%$ \\
\hline $\mathrm{Cs}^{135}$ (IM) & $2.24 \mathrm{E}+00$ & - & $1.82 \mathrm{E}+00$ & - & $-19 \%$ \\
\hline $\mathrm{Cs}^{137}$ (IM) & $3.18 \mathrm{E}+00$ & - & $2.62 \mathrm{E}+00$ & - & $-17 \%$ \\
\hline
\end{tabular}

*Single value

** Average of two replicates

*** The percent difference was calculated by subtracting the Un-Aged value from the Aged value and dividing by the UnAged value.

QC Flags: none - meets all QC

$\mathrm{U}_{\mathrm{B}}$ - blank exceeds $5 \%$ of sample concentration

$\mathrm{U}_{\mathrm{E}}$ - value less than 10x the DL
$\mathrm{U}_{\mathrm{R}}$ - fails \%RSD criteria

$\mathrm{U}_{\mathrm{L}}$ - fails \% Recovery of LCS

ND - not detected

$\mathrm{U}_{\mathrm{M}}$ - fails minimum MRQ criteria

$\mathrm{U}_{\mathrm{S}}$ - fails \% Recovery of MS

N/A - not applicable 
WSRC-TR-2003-00379, REV. 0

SRT-RPP-2003-00181, REV. 0

Table 5-6. Comparison of the Un-Aged and Aged 7 M Diluted 241-AW-101 Sample continued

\begin{tabular}{|c|c|c|c|c|c|}
\hline Analyte & $\begin{array}{l}\text { Un-Aged } \\
\text { Average } \\
(\mathrm{mCi} / \mathbf{L})\end{array}$ & $\begin{array}{l}\text { Un-Aged } \\
\text { QC Flag }\end{array}$ & $\begin{array}{c}\text { Aged } \\
\text { Average } \\
(\mathrm{mCi} / \mathbf{L})\end{array}$ & $\begin{array}{c}\text { Aged } \\
\text { QC Flag }\end{array}$ & $\begin{array}{c}\text { Percent } \\
\text { Difference } * * *\end{array}$ \\
\hline $\mathrm{Cs}^{137}$ (GS) & $2.57 \mathrm{E}+02$ & - & $2.92 \mathrm{E}+02$ & - & $14 \%$ \\
\hline $\mathrm{Eu}^{154}(\mathrm{GS})$ & $<6.1 \mathrm{E}-01$ & $\mathrm{U}_{\mathrm{M}}$ & $<6.2 \mathrm{E}-05$ & - & - \\
\hline $\mathrm{Eu}^{155}(\mathrm{GS})$ & $<1.5 \mathrm{E}+00$ & $\mathrm{U}_{\mathrm{M}}$ & $<2.3 \mathrm{E}-04$ & - & - \\
\hline $\mathrm{Co}^{60}(\mathrm{GS})$ & $<1.6 \mathrm{E}-01$ & $\mathrm{U}_{\mathrm{M}}$ & $3.72 \mathrm{E}-04$ & - & - \\
\hline $\mathrm{Sn}^{126}$ (GS) & $<1.4 \mathrm{E}+00$ & $\mathrm{U}_{\mathrm{M}}$ & $<4.9 \mathrm{E}-04$ & - & - \\
\hline $\mathrm{Pa}^{231}$ (GS) & $<3.0 \mathrm{E}+01$ & $\mathrm{U}_{\mathrm{M}}$ & $<3.1 \mathrm{E}-03$ & $\mathrm{U}_{\mathrm{M}}$ & - \\
\hline $\mathrm{Sr}^{90}(\mathrm{SL})$ & $6.32 \mathrm{E}-02$ & - & $4.56 \mathrm{E}-02$ & - & $-28 \%$ \\
\hline $\mathrm{Se}^{79}(\mathrm{SL})$ & - & - & $2.60 \mathrm{E}-04^{*}$ & $\mathrm{U}_{\mathrm{E}}$ & - \\
\hline $\mathrm{H}^{3}$ (SL) & $<1.4 \mathrm{E}-02$ & - & $2.49 \mathrm{E}-03$ & - & - \\
\hline $\mathrm{C}^{14}(\mathrm{SL})$ & $7.18 \mathrm{E}-04 * *$ & $\mathrm{U}_{\mathrm{E}}$ & $<6.1 \mathrm{E}-04$ & - & - \\
\hline $\mathrm{Tc}^{99}{ }_{\text {pertech }}(\mathrm{SL})$ & $1.12 \mathrm{E}-01$ & - & $1.04 \mathrm{E}-01$ & - & $-7 \%$ \\
\hline $\mathrm{I}^{129}(\mathrm{SG})$ & $1.81 \mathrm{E}-04$ & - & $1.49 \mathrm{E}-04$ & - & $-18 \%$ \\
\hline $\mathrm{Pu}^{238}(\mathrm{SA})$ & 7.64E-04 & $\mathrm{U}_{\mathrm{R}}$ & $6.26 \mathrm{E}-04$ & - & $-18 \%$ \\
\hline $\mathrm{Pu}^{239 / 240}(\mathrm{SA})$ & $2.04 \mathrm{E}-04$ & - & $1.15 \mathrm{E}-04$ & $\mathrm{U}_{\mathrm{R}}$ & $-44 \%$ \\
\hline $\mathrm{Pu}^{241}(\mathrm{SA})$ & $<9.5 \mathrm{E}-04$ & - & $8.28 \mathrm{E}-04$ & $\mathrm{U}_{\mathrm{R}}$ & - \\
\hline $\mathrm{Am}^{241}(\mathrm{SG})$ & $4.86 \mathrm{E}-04^{*}$ & - & $<2.7 \mathrm{E}-02$ & - & - \\
\hline $\mathrm{Cm}^{242}(\mathrm{SA})$ & $<6.9 \mathrm{E}-06$ & - & $<1.3 \mathrm{E}-04$ & - & - \\
\hline $\mathrm{Cm}^{243 / 244}(\mathrm{SA})$ & $6.37 \mathrm{E}-04$ & $\mathrm{U}_{\mathrm{B}} \mathrm{U}_{\mathrm{R}}$ & $<1.4 \mathrm{E}-03$ & - & - \\
\hline $\mathrm{Tc}^{99}$ total (IM) & $9.73 \mathrm{E}-02$ & - & $1.11 \mathrm{E}-01$ & - & $14 \%$ \\
\hline $\mathrm{Np}^{237}$ (IM) & $<2.7 \mathrm{E}-06$ & - & $<3.6 \mathrm{E}-06$ & - & - \\
\hline $\mathrm{Pu}^{239}$ (IM) & $4.41 \mathrm{E}-04$ & $\mathrm{U}_{\mathrm{E}}$ & $<3.1 \mathrm{E}-04$ & - & - \\
\hline $\mathrm{Pu}^{240}$ (IM) & $<8.7 \mathrm{E}-04$ & - & $<1.1 \mathrm{E}-03$ & - & - \\
\hline $\mathrm{U}^{233}$ (IM) & $<3.7 \mathrm{E}-05$ & - & $<4.9 \mathrm{E}-05$ & - & - \\
\hline $\mathrm{U}^{234}$ (IM) & $<2.4 \mathrm{E}-05$ & - & $<3.2 \mathrm{E}-05$ & - & - \\
\hline
\end{tabular}

* Single value

** Average of two replicates

*** The percent difference was calculated by subtracting the Un-Aged value from the Aged value and dividing by the UnAged value.

QC Flags: none - meets all QC

$\mathrm{U}_{\mathrm{B}}$ - blank exceeds $5 \%$ of sample concentration

$\mathrm{U}_{\mathrm{E}}$ - value less than 10x the DL
$\mathrm{U}_{\mathrm{R}}$ - fails \%RSD criteria

$\mathrm{U}_{\mathrm{L}}$ - fails \% Recovery of LCS

ND - not detected

$\mathrm{U}_{\mathrm{M}}$ - fails minimum MRQ criteria

$\mathrm{U}_{\mathrm{S}}$ - fails \% Recovery of MS

N/A - not applicable 
WSRC-TR-2003-00379, REV. 0

SRT-RPP-2003-00181, REV. 0

Table 5-6. Comparison of the Un-Aged and Aged 7 M Diluted 241-AW-101 Sample continued

\begin{tabular}{|l|c|c|c|c|c|}
\hline \multicolumn{1}{|c|}{ Analyte } & $\begin{array}{c}\text { Un-Aged } \\
\text { Average } \\
(\mathbf{m C i} / \mathrm{L})\end{array}$ & $\begin{array}{c}\text { Un-Aged } \\
\text { QC Flag }\end{array}$ & $\begin{array}{c}\text { Aged } \\
\text { Average } \\
(\mathbf{m C i} / \mathbf{L})\end{array}$ & $\begin{array}{c}\text { Aged } \\
\text { QC Flag }\end{array}$ & $\begin{array}{c}\text { Percent } \\
\text { Difference*** }\end{array}$ \\
\hline $\mathrm{U}^{235}(\mathrm{IM})$ & $3.38 \mathrm{E}-08$ & $\mathrm{U}_{\mathrm{E}}$ & $3.09 \mathrm{E}-08$ & $\mathrm{U}_{\mathrm{E}}$ & $-8 \%$ \\
\hline $\mathrm{U}^{236}(\mathrm{IM})$ & $<2.5 \mathrm{E}-07$ & - & $<3.3 \mathrm{E}-07$ & - & - \\
\hline $\mathrm{U}^{238}(\mathrm{IM})$ & $5.95 \mathrm{E}-07$ & - & $5.58 \mathrm{E}-07$ & $\mathrm{U}_{\mathrm{B}}$ & $-6 \%$ \\
\hline Alpha (AC) & $2.25 \mathrm{E}-02 * *$ & $\mathrm{U}_{\mathrm{E}} \mathrm{U}_{\mathrm{R}}$ & $5.31 \mathrm{E}-03$ & $\mathrm{U}_{\mathrm{E}} \mathrm{U}_{\mathrm{R}}$ & $-79 \%$ \\
\hline Alpha ${ }_{\text {sum }}$ & $1.45 \mathrm{E}-03 *$ & - & $<2.9 \mathrm{E}-02$ & - & - \\
\hline $\begin{array}{l}\text { Density } \\
\text { g/mL }\end{array}$ & 1.42 & - & 1.38 & - & $-3 \%$ \\
\hline $\begin{array}{l}\text { Wt\% } \\
\text { Dissolved } \\
\text { Solids }\end{array}$ & $29.0 \%$ & Low Biased & $43.1 \%$ & - & $49 \%$ \\
\hline $\begin{array}{l}\text { Wt\% } \\
\begin{array}{l}\text { Insoluble } \\
\text { Solids }\end{array}\end{array}$ & $0.32 \%$ & - & $0.14 \%$ & Low Biased & $-55 \%$ \\
\hline
\end{tabular}

*Single value

** Average of two replicates

*** The percent difference was calculated by subtracting the Un-Aged value from the Aged value and dividing by the UnAged value.

QC Flags: none - meets all QC

$\mathrm{U}_{\mathrm{B}}$ - blank exceeds $5 \%$ of sample concentration

$\mathrm{U}_{\mathrm{E}}$ - value less than $10 \mathrm{x}$ the DL

$\mathrm{U}_{\mathrm{R}}$ - fails \%RSD criteria

$\mathrm{U}_{\mathrm{L}}$ - fails \% Recovery of LCS

ND - not detected
$\mathrm{U}_{\mathrm{M}}$ - fails minimum MRQ criteria

$\mathrm{U}_{\mathrm{S}}$ - fails \% Recovery of MS

N/A - not applicable 
WSRC-TR-2003-00379, REV. 0

SRT-RPP-2003-00181, REV. 0

This page intentionally left blank. 
WSRC-TR-2003-00379, REV. 0

SRT-RPP-2003-00181, REV. 0

\subsection{GENERAL DESCRIPTION OF ANALYTICAL PROCEDURES}

\subsection{INDUCTIVELY COUPLED PLASMA-ATOMIC EMISSION SPECTROSCOPY}

Samples were diluted as necessary to bring analytes within the instrument range. A scandium internal standard was added to all samples after dilution at a concentration of $2 \mathrm{mg} / \mathrm{L}$. Background and internal standard correction were applied to the results. An LCS containing the analytes of interest was run with the samples. A matrix spike containing $\mathrm{Ba}, \mathrm{Ca}, \mathrm{Cr}, \mathrm{Fe}$, $\mathrm{Na}$, and Ni was run with each set of samples. The subset of elements used for the matrix spike was specified in the task plan.

\subsection{ION CHROMATOGRAPHY FOR ANIONS AND ORGANICS ACIDS}

For IC Anions, samples were diluted with a carbonate/bicarbonate diluent as necessary to bring analytes to within instrument calibration. An LCS containing the analytes of interest was analyzed concurrently with samples. One sample replicate was spiked with known concentrations of the analytes of interest for each set of samples.

Organic acids were determined by ion exclusion chromatography (IEC). Samples were diluted in a high salt solution as necessary to bring analytes to within instrument calibration. An LCS containing the analytes of interest was analyzed concurrently with samples. One sample replicate was spiked with known concentrations of the analytes of interest for each set of samples.

\subsection{FREE HYDROXIDE AND TOTAL BASE TITRATIONS}

Total hydroxide (total base) was determined by titration to an inflection end point closest to $\mathrm{pH}$ 7.00. An LCS containing $1.00 \mathrm{~N} \mathrm{NaOH}$ was run in triplicate before and after each set of samples.

Free hydroxide was determined by incremental inflection point titration. The titration curves were examined to determine the free hydroxide concentration. A lab control standard containing hydroxide, aluminate, and carbonate was run in triplicate before and after each set of samples.

Carbonate was determined by precipitation using saturated barium chloride. The precipitate was dissolved in acid and the carbonate concentration determined via back titration. An LCS containing hydroxide, aluminate, and carbonate was run in triplicate before and after each set of samples.

No matrix spikes were performed on any of the base titrations. 


\subsection{ATOMIC ABSORPTION SPECTROSCOPY}

Sodium, potassium, and mercury were analyzed by AA. The mercury was determined using the cold vapor technique. Samples were diluted as necessary to bring analytes within the instrument calibration range. An LCS containing the analyte of interest was run with the samples. A matrix spike containing the analyte of interest was made on one of the sample replicates for each set of samples.

\subsection{AMMONIA}

Ammonia was analyzed by ion (cation) chromatography after a purge and trap procedure to isolate the ammonia from the sample.

Due to high concentrations of sodium ions which interfere with the analysis of ammonium ions (NH4+), dissolved ammonia in the sample was purged using helium gas and trapped in an acidic solution for cation analysis. A 1-mL sample aliquot was added to a 2 molar hydroxide solution and purged for 15 minutes. An LCS containing the sample analyte was analyzed concurrently with samples. A sample replicate was spiked with the analyte at a known concentration, purged for 15 minutes, and trapped in an acidic solution for cations analysis. Measured values were adjusted to account for purge efficiency losses.

\subsection{ORGANICS}

EDTA and HEDTA were analyzed by Ion Pair Chromatography (IPC). The copper complex of EDTA and HEDTA were used as the LCS. For the matrix spike, EDTA and HEDTA were spiked into the sample followed by preparation and analysis.

IDA, NTA, and ED3A were analyzed by GC-MS. These compounds were converted from carboxylic acids to methyl esters by $\mathrm{BF}_{3} /$ methanol reagent for $\mathrm{GC}-\mathrm{MS}$ analysis. The GC-MS instrument was calibrated using naphthalene-d8 as the LCS. The matrix spike was either Adipic acid or stearic-d35 acid which was then compared to acid methyl ester. Each sample was prepared in duplicate, one containing a spike of IDA and NTA. The IDA/NTA spike served as an internal standard.

\subsection{TOTAL INORGANIC CARBON/TOTAL ORGANIC CARBON}

Total carbon was determined by combustion at $780{ }^{\circ} \mathrm{C}$ in a stream of pure oxygen. The $\mathrm{CO}_{2}$ produced was then measured. The inorganic carbon was determined by injecting an aliquot into an acid medium purged by an oxygen stream. Again, the $\mathrm{CO}_{2}$ produced was then measured. By subtracting the inorganic carbon from the total carbon, the organic carbon was calculated. Instrument calibration used NIST traceable organic and inorganic standards before and after each set of samples. These standards also served as the LCS and were used for the matrix spike for the method. The matrix spike was made on one of the sample replicates. 


\subsection{INDUCTIVELY COUPLED PLASMA-MASS SPECTROMETRY}

Samples were run concurrently with an LCS containing V, Co, As, Sr, Mo, Ru, Ag, Cd, Sb, $\mathrm{Cs}, \mathrm{Ba}, \mathrm{La}, \mathrm{Eu}, \mathrm{Ho}, \mathrm{Yb}, \mathrm{Tl}, \mathrm{Pb}, \mathrm{Th}$, and $\mathrm{U}$. This LCS provided a mass response covering most of the mass range of interest. However, the LCS did not cover every mass of species of interest such as $\mathrm{I}^{127}$, and $\mathrm{W}$ isotopes so no LCS recovery was provided for these analytes. In general a matrix spike using the LCS was made on one of the sample replicates. For some of the sample results without matrix spike recoveryies in the data tables, a matrix spike containing only $U$ was used. The following describes the calculation of the analytes of interest from the mass values:

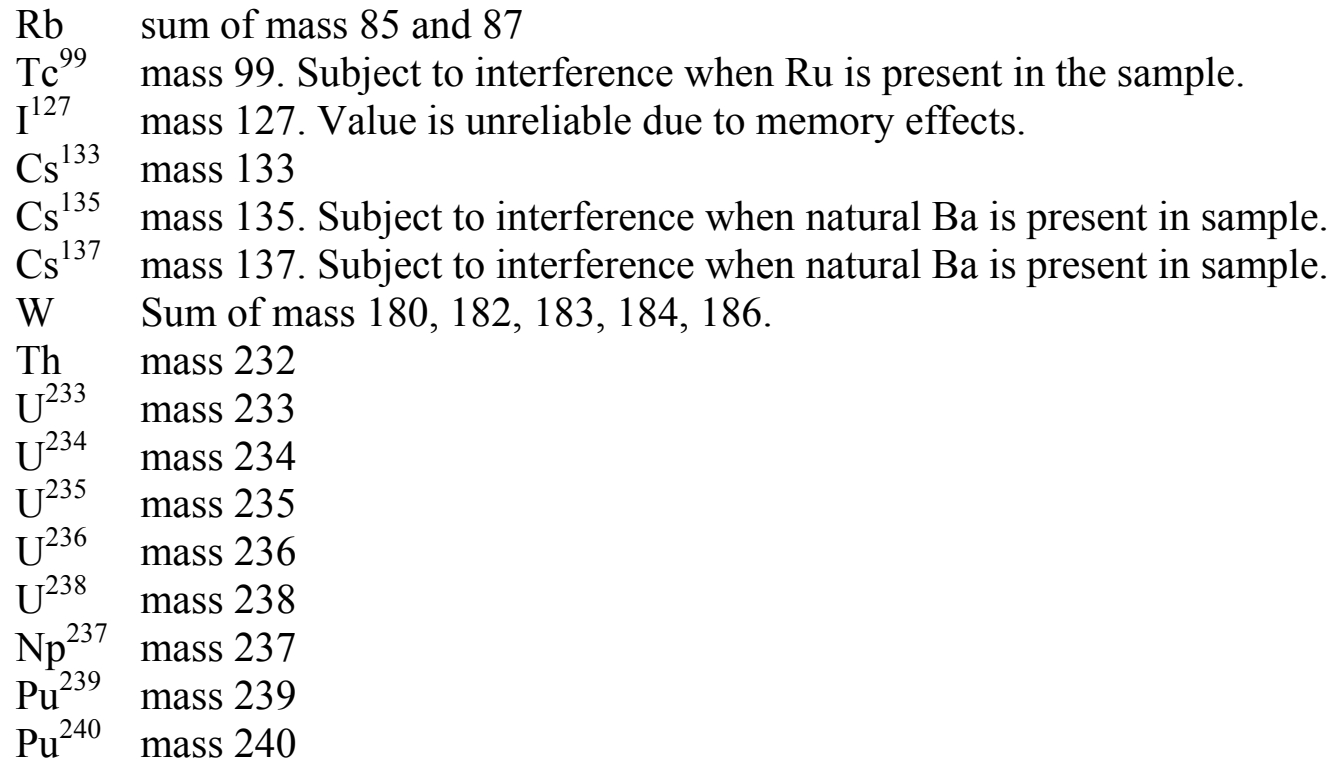

\subsection{ALPHA COUNTING}

Prior to the analysis, $\mathrm{Cs}^{137}$ was removed from aliquots of the samples in order to reduce bias effects caused by large beta/alpha ratios. The $\mathrm{Cs}^{137}$ removal was accomplished using BioRad AMP1 resin. Following the Cs removal process, an aliquot of each stripped solution was added to a stainless steel planchet and analyzed for alpha activity.

\subsection{GAMMA SPECTROMETRY}

An aliquot of each sample was analyzed by gamma spectroscopy analysis using a high purity germanium detector. Results are background subtracted. 


\subsection{1 $\mathrm{H}^{3}$ ANALYSIS}

For the tritium analysis, an aliquot of each sample was subjected to a steam distillation to separate the tritium-containing fraction from the remainder of the sample. An aliquot of each distillate was added to liquid scintillation cocktail to be analyzed for tritium. The samples were counted on a Packard Instruments liquid scintillation counter along with an instrument blank. The instrument blank was counted first and was used to establish an instrument background that was subtracted from the count results for the samples.

\subsection{2 $\mathrm{Tc}^{99}$ ANALYSIS (FOR PERTECHNETATE FORM)}

$\mathrm{Tc}^{99 \mathrm{~m}}$ tracers were generated initially by neutron irradiation of natural molybdenum using SRTC's Cf ${ }^{252}$ Neutron Activation Analysis facility. $\mathrm{Mo}^{98}$ was activated to $\mathrm{Mo}^{99}$ which subsequently beta decays to $\mathrm{Tc}^{99 \mathrm{~m}}$. The $\mathrm{Tc}^{99 \mathrm{~m}}$ was then extracted from the $\mathrm{Mo}^{99}$ to form a $\mathrm{Tc}^{99 \mathrm{~m}}$ tracer.

Aliquots of the sample were diluted with water, $\mathrm{Tc}^{99 \mathrm{~m}}$ tracer was added, and the $\mathrm{Tc}^{99}$ was subsequently extracted using an Aliquat 336 based extraction. Aliquat 336 extracts $\mathrm{Tc}^{99}$ in the pertechnetate form. The extractant was then analyzed first by gamma spectroscopy to determine $\mathrm{Tc}^{99 \mathrm{~m}}$ tracer recoveries, and then analyzed by liquid scintillation analysis to determine $\mathrm{Tc}^{99} . \mathrm{Tc}^{99 \mathrm{~m}}$ tracer recoveries were applied to the liquid scintillation results to quantify the $\mathrm{Tc}^{99}$. A blank solution was also run through the extraction process to ensure no cross contamination existed at the laboratory level.

\subsection{3 $\mathrm{Sr}^{90}$ ANALYSIS}

An aliquot of each sample was analyzed for $\mathrm{Sr}^{90}$ using an Eichrom Sr-Spec based extraction procedure. A $\mathrm{Sr}^{90}$ spiked blank was analyzed with the sample batch to establish $\mathrm{Sr}^{90} / \mathrm{Y}^{90}$ counting efficiencies and $\mathrm{Sr}$ chemical recoveries. Aliquots of the $\mathrm{Sr}$ from each sample extract were analyzed by neutron activation analysis to determine $\mathrm{Sr}$ carrier recoveries, the results of which were normalized to the results of the $\mathrm{Sr}^{90}$ spiked blank sample so each sample could be yielded by the recovery of its stable Sr carrier recovery. The LCS and matrix spike samples were treated exactly like the samples. Once the extractions were complete, aliquots of the resultant $\mathrm{Sr}^{90} / \mathrm{Y}^{90}$ containing extracts, mixed with liquid scintillation cocktail, were counted in the ADS Radiochemistry Counting Facility. The samples were counted on a Packard Instruments liquid scintillation counter along with an instrument blank. The instrument blank was counted first and was used to establish an instrument background that was subtracted from the count results for the samples. 


\subsection{4 $\mathrm{Se}^{79}$ ANALYSIS}

Aliquots of the sample were spiked initially with stable Se which acted as both a chemical carrier and a Se yield tracer for the $\mathrm{Se}^{79}$ measurements. The samples were then oxidized. Next the solutions were reduced to precipitate out Se metal. The Se metal was washed repeatedly, redissolved, and the dissolution was then subjected to a series of decontamination steps with several types of analytical resins added in batch mode, which were subsequently filtered off. The decontaminated solutions were then concentrated. Aliquots of the concentrate were analyzed by neutron activation analysis to determine Se carrier yields, and by liquid scintillation to measure $\mathrm{Se}^{79}$ activities.

\subsection{ALPHA SPECTROSCOPY FOR PLUTONIUM ISOTOPICS}

An aliquot of each sample dissolution was subjected to a thenoyltrifluoroacetone (TTA) separation. An aliquot of the sample dissolution was initially spiked with a $\mathrm{Pu}^{238}$ tracer. A second aliquot of straight sample dissolution was analyzed along with the spiked sample. In addition, a third aliquot was used for determining the $\mathrm{Pu}^{241}$ concentration. The plutonium in the samples was reduced once using hydroxylamine. An anion complexing reagent (aluminum nitrate) was then added, and the solutions were oxidized with 4M sodium nitrite. The plutonium was then extracted from the matrix using a TTA solution. The TTA layer was mounted on a counting dish, the mount was then analyzed by alpha spectroscopy. A blank sample was run with the sample set.

The analysis results for the $\mathrm{Pu}^{239 / 240}$ alpha peak were yielded using the $\mathrm{Pu}^{238}$ recoveries from the $\mathrm{Pu}^{238}$ traced sample separation. The ratio of the $\mathrm{Pu}^{239 / 240}$ to the $\mathrm{Pu}^{238}$ in the sample was obtained from the alpha spectroscopy analysis of the non-spiked sample. That ratio was applied to the determined $\mathrm{Pu}^{239 / 240}$ value to determine the $\mathrm{Pu}^{238}$ activity in the sample.

The sample aliquot dedicated to the $\mathrm{Pu}^{241}$ analysis was added to liquid scintillation cocktail following the separation and analyzed for both $\mathrm{Pu}^{241}$ and gross $\mathrm{Pu}$-alpha constituents. The ratio of $\mathrm{Pu}^{241}$ to total $\mathrm{Pu}$ alpha was determined and applied to the results from the plates in order to determine a $\mathrm{Pu}^{241}$ concentration.

\section{$6.16 I^{129}$ ANALYSIS}

An aliquot of each sample was spiked with stable iodide and was subjected to a silver iodide precipitation method to separate any iodide in the matrix from other radionuclides. A blank DI water sample was analyzed along with the batch. The precipitates were analyzed for $\mathrm{I}^{129}$ activity with a low energy HPGe gamma spectroscopy detector. After the gamma analyses, the precipitates were analyzed by neutron activation analysis (NAA) to determine the levels of stable iodide carrier in the precipitates. The recoveries of the iodide carrier were used to correct the gamma spectroscopy results for the $\mathrm{I}^{129}$ recoveries. Uncertainties provided are 1 sigma. 


\subsection{Am/Cm ANALYSIS}

Aliquots of sample were run through a $\mathrm{Am} / \mathrm{Cm}$ separation procedure to separate the trivalent $\mathrm{Am} / \mathrm{Cm}$ isotopes from the higher valence state actinides following a sample oxidation step. Samples were run through the procedure in duplicate, one sample spiked with $\mathrm{Am}^{243}$ for yielding purposes, one sample unspiked to correct for any $\mathrm{Am}^{243}$ that may be present in the samples. The Am/Cm sample mount was analyzed by alpha spectroscopy for $\mathrm{Cm}^{244 / 243}$ and $\mathrm{Cm}^{242}$ and by low energy gamma spectrometry for $\mathrm{Am}^{241}$. The results were yielded by using the $\mathrm{Am}^{243}$ tracer alpha result and the $\mathrm{Am}^{243}$ tracer gamma result. A blank sample was run through all of the analyses with every batch of samples.

\section{$6.18 \mathrm{C}^{14}$ ANALYSIS}

Aliquots of sample were wet-ashed with a sodium persulfate/silver nitrate oxidation in conjunction with concentrated sulfuric acid. The carbon dioxide emitted was absorbed with Packard Instruments Carbosorb E. The Carbosorb E was then slurried into Ultima Gold AB, and analyzed by liquid scintillation analysis for $\mathrm{C}^{14}$. Each sample was run through the process in duplicate. A blank solution, spiked with a $\mathrm{C}^{14}$ standard, was run (in duplicate) in parallel with the samples to determine $C^{14}$ recoveries. The average recoveries were applied to the sample results to quantify the $\mathrm{C}^{14}$ concentrations. A second blank solution, spiked with the $\mathrm{C}^{14}$ standard was also run in duplicate through the process to serve as the laboratory control sample. One customer sample was spiked with some $\mathrm{C}^{14}$ (again in duplicate) and run through the process to serve as the matrix spike. A blank solution was also run through the entire process to ensure no cross contamination existed at the laboratory level. 


\subsection{REFERENCES}

1. Hay, M. S., Coleman, C. J., Martin, K. B., Compositing, Characterization, and Dilution of Samples from Hanford Tank 241-AW-101. WSRC-TR-2002-00509 Rev. 0, SRT-2002-00255 Rev. 0, April 15, 2003, Savannah River Site, Aiken, SC 29808.

2. Hay, M. S., Task Technical and Quality Assurance Plan for the Characterization and Dilution of Samples from Hanford Tank 241-AW-101, WSRC-TR-2001-00244, SRTRPP-2001-00063, Rev. 0, September 14, 2001, Savannah River Site, Aiken, SC 29808.

3. Lee, E., Burgeson, I., Tank 241-AW-101 Sample Composite, Homogeneity, Analysis, and Dilution - Test Specification, 24590-WTP-TSP-RT-01-001, Rev. 0, August 10, 2001.

4. Hay, M. S., Edwards, T. B., Statistical Analysis of ESP Verification Test Samples, WSRC-RP-94-1224, November 4, 1994, Savannah River Site, Aiken, SC 29808. 